Fall 2010

\title{
Polyethylene Retail Carrier Bags: Non-Market Economy Status and U.S. Unfair Trade Actions against Vietnam
}

David A. Gantz

Follow this and additional works at: https://scholarship.law.unc.edu/ncilj

\section{Recommended Citation}

David A. Gantz, Polyethylene Retail Carrier Bags: Non-Market Economy Status and U.S. Unfair Trade Actions against Vietnam, 36 N.C. J. INT'L L. 85 (2010).

Available at: https://scholarship.law.unc.edu/ncilj/vol36/iss1/4

This Article is brought to you for free and open access by Carolina Law Scholarship Repository. It has been accepted for inclusion in North Carolina Journal of International Law by an authorized editor of Carolina Law Scholarship Repository. For more information, please contact law_repository@unc.edu. 


\section{Polyethylene Retail Carrier Bags: Non-Market Economy Status and U.S. Unfair}

Trade Actions against Vietnam

\section{Cover Page Footnote}

International Law; Commercial Law; Law 


\title{
Polyethylene Retail Carrier Bags: Non-Market Economy Status and U.S. Unfair Trade Actions Against Vietnam
}

\author{
David A. Gantz†
}

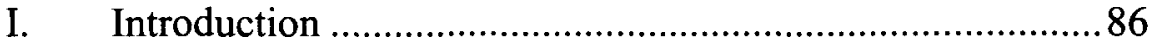

II. WTO Requirements Governing MNE Treatment for

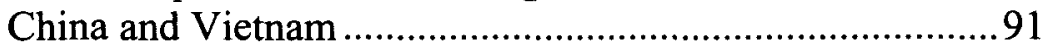

A. China's Accession Agreement .......................................92

B. Vietnam's WTO Accession ..........................................94

III. United States NME Law ....................................................98

A. United States Antidumping Law and NMEs ................98

B. Application of U.S. CVD Laws to NMEs....................106

IV. U.S. NME CVD Methodology and Practice - China .........111

V. U.S. Methodology and Practice - Vietnam:

Polyethylene Retail Carrier Bags (PRCBs) ....................... 115

A. PRCBs - CVD Action ............................................. 116

1. Applying CVD Law to Vietnam...........................116

2. Key Issues in the CVD Determination ...................118

B. The Determination of Dumping..................................122

C. The USITC's Material Injury Analysis........................125

VI. U.S. Methodology and Non-National Benchmarks in

Market Economy Situations: Canadian Softwood

Lumber......................................................................... 127

A. Commerce's CVD Investigation................................129

B. The WTO Appellate Body Decision............................130

VII. WTO Challenges to U.S. Methodology ............................132

VIII. Conclusion .......................................................................... 134

†Samuel M. Fegtly Professor of Law and Director, International Trade and Business Law Program, the University of Arizona, James E. Rogers College of Law; Associate Director, National Law Center for Inter-American Free Trade. An earlier version of this paper was presented in August 2009 at a conference sponsored by the Ho Chi Minh City Law University in HCM City, and benefitted from the comments received from other participants in that conference. Copyright $(\mathcal{2} 2009,2010$, David A. Gantz. All rights reserved. 


\section{Introduction}

Vietnam agreed in its Protocol of Accession to the World Trade Organization ("WTO")' that WTO Members could use the generally unfavourable non-market economy ("NME") methodology when conducting anti-dumping ("AD") ${ }^{2}$ and countervailing duty ("CVD") ${ }^{3}$ investigations, including, but not limited, to the use of factor of production data from "surrogate" countries in substitution for action Vietnamese production data. ${ }^{4}$

This unavoidable concession results in a continuing risk of anti-dumping, and recently, countervailing duty actions against Vietnamese exports, particularly those actions brought in United States and the European Union. The methodology has typically resulted in exaggerated dumping margins, as in Frozen Fish Fillets where the margins were in excess of forty-four percent. ${ }^{5}$ This is not always the case. The Vietnamese margins in the initial investigation in Final Determination of Sales at Less Than Fair Value: Certain Frozen and Canned Warmwater Shrimp From the

1 See World Trade Organization, Protocol on the Accession of the Socialist Republic of Viet Nam, WT/L/662 (Nov. 15, 2006) (incorporating the Report of the Working Party on the Accession of Viet Nam, If 255, WT/ACC/VNM/48 (Oct. 27, 2006)) [hereinafter Vietnamese Accession Protocol].

2 See General Agreement on Tariffs and Trade, Oct. 30, 1947, art. VI, 61 Stat. A11, 55 U.N.T.S. 194 [hereinafter GATT 1947]; Agreement on Implementation of Article VI of the General Agreement on Tariffs and Trade 1994, Dec. 15, 1993, Marrakesh Agreement Establishing the World Trade Organization, Annex 1A, Legal Instruments Results of the Uruguay Round, 33 U.L.M. 1125 (1994) [hereinafter Anti-dumping Agreement] (allowing for antidumping duties where export products are sold at less than fair value and cause material injury or threat of material injury to producers in the importing country).

3 See GATT 1947, supra note 2, arts. VI, XVI; Agreement on Subsidies and Countervailing Measures, Dec. 15, 1993, Marrakesh Agreement Establishing the World Trade Organization, Annex 1A, Legal Instruments - Results of the Uruguay Round, 33 U.L.M. 1125 (1994) [hereinafter SCM Agreement] (allowing for countervailing duties to be imposed when the subject imports are shown to enjoy government subsidies that confer a benefit, and such subsidies cause material injury or threat of material injury to producers in the importing country).

4 See, e.g., Notice of Final Antidumping Duty Determination of Sales at Less Than Fair Value and Affirmative Critical Circumstances: Certain Frozen Fish Fillets from the Socialist Republic of Vietnam, 68 Fed. Reg. 37116 (June 23, 2003) [hereinafter Frozen Fish Fillets].

5 See Frozen Fish Fillets, 68 Fed. Reg. at 37121. 
Socialist Republic of Vietnam were in the six percent range, ${ }^{6}$ i.e., near normal. In the CVD area these methods relate primarily to the use of non-national "benchmarks" when calculating the "benefit" from certain government subsidy programs, ${ }^{7}$ permitting the rejection of national data when government control of financial institutions or property leasing has led to data distortion or misrepresentation. ${ }^{8}$

In April 2009, The Department of Commerce ("DOC" or "Commerce") initiated $\mathrm{AD}$ and $\mathrm{CVD}$ actions against Vietnam relating to Polyethylene Retail Carrier Bags ("PRCBs"), the plastic bags used for packaging dry cleaning and other consumer products. $^{9}$ The action against Vietnamese producers followed a number of CVD actions by the United States against China beginning in $2006^{10}$ and the two earlier $\mathrm{AD}$ actions against Vietnam mentioned above. ${ }^{11}$ In August 2009, Commerce preliminarily determined the existence of actionable subsidies, albeit at relatively low sub-three percent rates in most instances. ${ }^{12}$ These findings were essentially confirmed in the final CVD determination, with CVD margins ranging from 0.44 percent (de minimis) to 5.28 percent except for one firm for which "adverse facts available" ("AFA") were used, resulting in much higher margins. ${ }^{13}$ The preliminary AD determination led to considerably

6 See Notice of Final Determination of Sales at Less Than Fair Value: Certain Frozen and Canned Warmwater Shrimp From the Socialist Republic of Vietnam, 69 Fed. Reg. 71005, 71009 (Dec. 8, 2004) [hereinafter Shrimp]

7 Working Party Report, Vietnam - Report of the Working Party on the Accession of Viet Nam, ๆ 255, WT/ACC/VNM/48 (Oct. 27, 2006) [hereinafter Vietnam Working Party Report].

8 See id. $\lceil 254$.

9 See Polyethylene Retail Carrier Bags from the Socialist Republic of Vietnam: Preliminary Affirmative Countervailing Duty Determination and Alignment of Final Countervailing Duty Determination with Final Antidumping Duty Determination, 74 Fed. Reg. 45811, 45811-13 (Sept. 4, 2009) [hereinafter PRCB Preliminary CVD Determination].

10 See, e.g., Coated Free Sheet Paper From the People's Republic of China: Amended Preliminary Affirmative Countervailing Duty Determination, 72 Fed. Reg. 17484 (Apr. 9, 2007).

11 See supra text accompanying notes $2,3$.

12 See PRCB Preliminary CVD Determination, 74 Fed. Reg. at 45820.

13 See Polyethylene Retail Carrier Bags From the Socialist Republic of Vietnam: Final Affirmative Countervailing Duty Determination, 75 Fed. Reg. 16428, 16430 (Apr. 
higher margins, from 52.3 percent to 76.11 percent; ${ }^{14}$ those results were confirmed without change in the final $\mathrm{AD}$ determination, since none of the parties participated further in the proceedings. ${ }^{15}$ In the $\mathrm{AD}$ proceedings, the magnitude of the margins was exaggerated by Commerce's use of $\mathrm{AFA},{ }^{16}$ explained in Part VI(B), ${ }^{17}$ with the result that the $\mathrm{AD}$ case is of little use in further illuminating Commerce practice in this third $\mathrm{AD}$ action against Vietnam. $^{18}$

The NME approach, particularly as it is applied in CVD actions, will likely continue to bedevil both the Vietnamese government and Vietnamese exporters to the United States unless the United States follows the lead of New Zealand and Australia by affording Vietnam market economy ("ME") treatment for some or all manufacturing sectors. ${ }^{19}$ Such action seems highly unlikely at the present time. Moreover, while there have been no European Union ("EU") CVD actions against Vietnam, ${ }^{20}$ the EU recently initiated such an action against China, relating to alleged Chinese subsidies of glossy paper. ${ }^{21}$ The risks of similar EU proceedings against Vietnam, although perhaps not immediate, are obvious.

In many respects, the NME issue, at least from an economic

1, 2010) [hereinafter PRCB Final CVD Determination].

14 See Polyethylene Retail Carrier Bags From the Socialist Republic of Vietnam: Preliminary Determination of Sales at Less Than Fair Value and Postponement of Final Determination, 74 Fed. Reg. 56813, 56819 (Nov. 3, 2009) [hereinafter PRCB Preliminary AD Determination].

15 See Polyethylene Retail Carrier Bags from the Socialist Republic of Vietnam: Final Determination of Sales at Less Than Fair Value, 75 Fed. Reg. 16434, 16434-35 (Apr. 1, 2010) [hereinafter PRCB Final AD Determination].

16 Id.

17 See infra note 18.

18 PRCB Final AD Determination, 75 Fed. Reg. at 56819.

19 See Australian Ministry of Trade, Press Release, Market Economy Status for Vietnam (Feb. 27, 2009), http://www.trademinister.gov.au/releases/2009/sc_018.html.

20 See World Trade Organization, Disputes By Agreement (as cited in request for consultation),

http://www.wto.org/english/tratop_e/dispu_e/dispu_agreements_index_e.htm?id=A20\#s elected_agreement (last visited Oct. 26, 2010) (listing disputes against Member nations by other Member nations).

21 Joe Kirwin, EU Investigates Chinese Glossy Paper, Marks First-Ever China Anti-Subsidy Probe, 27 INT'L TRADE ReP. (BNA) 580 (Apr. 22, 2010) (describing the institution of an investigation by the European Commission into Chinese subsidies). 
point of view, is not whether the Protocol on the Accession of the People's Republic of China and the Vietnamese Accession Protocol legally permit entities such as the United States and the EU to treat China and Vietnam differently in $A D$ and CVD actions. However, regardless of the legal issue, it makes little economic sense to contend that there is a clear, economy-wide divide between NMEs and MEs in such circumstances, even if the level of government involvement in the economy in MNEs, such as China and Vietnam, remains considerably greater than in most so-called MEs. As the discussion of Georgetown Steel Corp. v. United States ${ }^{22}$ indicates, the traditional distinction between NMEs and MEs in U.S. CVD practice, precluding the use of CVD actions against the former, evolved more than twenty-five years ago when a sharp division existed between centrally-planned economies such as the Soviet Union, and those in which factors of production and selling prices are determined by market forces. This distinction has blurred greatly in recent years. ${ }^{23}$

Clearly, the Chinese and Vietnamese governments continue to play major roles in their economies. Many government decisions and policies distort the market system. Examples include government control of commercial banking, land use prices, and industry favouritism. ${ }^{24}$ Many other governments have been interfering extensively in major sectors of the economy. For example, the United States has heavily regulated the banking, mortgage loans, health care and the automobile sectors. ${ }^{25}$ The major world economies may well be entering an era shifting away from the "laissez faire" approach to government regulation and participation in the economy, a trend which began during the

22 Georgetown Steel Corp. v. United States, 801 F.2d 1308 (Fed. Cir. 1986) (discussed infra Part III).

23 See Adam McCarty \& Carl Kalapesi, The Economics of the "Non-Market Economy" Issue: Vietnam Catfish Case Study 4 (Vietnamese Ministry of Economics, Working Paper, Jan. 29, 2003).

24 See Philippe Auffret, Trade Reform in Vietnam: Opportunities with Emerging Challenges 5-8 (World Bank, Policy Research Working Paper No. 3076, June 2003) (describing existing concerns regarding state-owned industries and state-owned banks in Vietnam).

25 See Andrew Martin, Give Him Liberty, but Not a Bailout, N.Y. TIMES, Aug. 2, 2009 , at B1, B6 (discussing the varying amounts of United States governmental involvement in banking, the automotive industry, health care, and mortgage loans). 
Reagan era in the United States and the Thatcher era in the United Kingdom, and has since spread elsewhere. Governments' reactions to the "Great Recession" of 2009 suggest that efforts to characterize economies as NME or ME will likely make less economic sense for purposes of applying national unfair trade laws.

Vietnam and China must deal with the realities of United States law and practice, and with the obligations the two governments accepted when acceding to the WTO, for some years to come. Moreover, because the United States, EU, and other WTO Members are much more concerned about China's exports than Vietnam's, any major change by WTO members in treatment of Vietnam likely depends on a policy change with regard to China, since the rationale for NME treatment is similar for both nations. Because few WTO Members other than the United States, the European Union and Canada commonly bring CVD actions, the threat of trade disruption from $\mathrm{AD}$ actions is a more serious concern for both Vietnam and China. ${ }^{26}$

The focus of this article is the PCRB CVD action brought in the United States against Vietnam. CVD actions against China have been discussed elsewhere. ${ }^{27}$ Part II discusses the WTO requirements for applying NME methodology to WTO Members in both $\mathrm{AD}$ and CVD actions, as reflected in the Chinese and Vietnamese WTO accession agreements. Part III addresses U.S. NME law and practice, focusing on the determination that Vietnam is a NME for antidumping actions in Frozen Fish Fillets. Part IV briefly reviews the methodology used by the United States authorities in bringing CVD actions against China beginning in 2006. Part V addresses key aspects of the U.S. agency determinations - CVD, AD and injury-in PRCBs, with emphasis

26 World Trade Organization, Countervailing Initiations: By Reporting Member 01/01/1995 - 31/12/2009,

http://www.wto.org/english/tratop_e/scm_e/cvd_init_rep_member_e.pdf (displaying all 215 CVD investigations reported to the WTO between Jan. 2, 1995, and Dec. 31, 2008, 179 of which were brought by five Members: the United States (88), EU (48), Canada (23), South Africa, (11), and Australia (9)).

27 See, e.g., James P. Durling, Encountering Rocky Shoals: Application of the CVD Law to China, GULC Int'l Trade Update, 2010 WL 956090, Feb. 2010; G. Bowman, N. Covelli, D. Gantz, I. Uhm, TRADE REMEDIES IN NORTH AMERICA 128-30 (Kluwer Int'l, 2010). 
on the ground-breaking CVD analysis. Part VI reviews a key CVD action which was unsuccessfully challenged in the WTO's Dispute Settlement Body against Canada, a market economy, regarding Canadian softwood lumber. The case blurs ME and NME distinctions in critical aspects of United States CVD practice. The article also discusses briefly, in Part VII, the prospects for questioning the United States' NME practices "as applied" 28 in the Dispute Settlement Body of the WTO ("Dispute Settlement Body"), ${ }^{29}$ as with recent Chinese challenges to United States $^{30}$ and EU practices. ${ }^{31}$ Part VIII is a brief summary and conclusion.

\section{WTO Requirements Governing MNE Treatment for China and Vietnam}

Both China and Vietnam were required as a condition of accession to accept special and less favorable treatment with regard to $A D$ and $C V D$ actions brought by other Members against them. $^{32}$ Thus, in the author's view the use of NME methodology will be virtually impossible to challenge successfully "as such" before the Dispute Settlement Body; whether challenges to such legislation "as applied" will be feasible remains to be seen and are discussed briefly below. However, also as discussed below, there may be other avenues which would permit challenges in Geneva.

28 See Request for the Establishment of a Panel by China, United States Definitive Anti-Dumping and Countervailing Duties on Certain Products from China, 37, WT/DS379, Dec. 12, 2008 (providing an example of "as applied" disputes).

29 See Understanding on Rules and Procedures Governing the Settlement of Disputes, Apr. 15, 1994, Marrakesh Agreement Establishing the World Trade Organization, Annex 2, Legal Instruments - Results of the Uruguay Round, 33 I.L.M. 1125 (1994) [hereinafter Dispute Settlement Understanding].

30 See Request for the Establishment of a Panel by China, supra note 28.

31 See Request for Consultations by China, European Communities - Definitive Anti-Dumping Measures On Certain Iron or Steel Fasteners From China, WT/DS397/1, Aug. 4, 2009.

32 See World Trade Organization, Protocol on the Accession of the People's Republic of China, WT/L/432 (Nov. 10, 2001) (incorporating the Report of the Working Party on the Accession of China, I 150, WT/ACC/C.HN/49 (October 1, 2001)) [hereinafter Chinese Accession Agreement]; Vietnam Working Party Report, supra note 7, ๆ 255 . 
A. China's Accession Agreement

In 2001, China, upon entering the WTO, accepted the SCM Agreement and the applicability of its provisions relating to CVD actions. ${ }^{33}$ Also, China agreed in its WTO Accession Agreement to the following language:

15. Price Comparability in Determining Subsidies and Dumping

Article VI of the GATT 1994, the Agreement on Implementation of Article VI of the General Agreement on Tariffs and Trade 1994 ("Anti-Dumping Agreement") and the SCM Agreement shall apply in proceedings involving imports of Chinese origin into a WTO Member consistent with the following:

(a) In determining price comparability under Article VI of the GATT 1994 and the Anti-Dumping Agreement, the importing WTO Member shall use either Chinese prices or costs for the industry under investigation or a methodology that is not based on a strict comparison with domestic prices or costs in China based on the following rules:

(i) If the producers under investigation can clearly show that market economy conditions prevail in the industry producing the like product with regard to the manufacture, production and sale of that product, the importing WTO Member shall use Chinese prices or costs for the industry under investigation in determining price comparability;

(ii) The importing WTO Member may use a methodology that is not based on a strict comparison with domestic prices or costs in China if the producers under investigation cannot clearly show that market economy conditions prevail in the industry producing the like product with regard to manufacture, production and sale of that product.

(b) In proceedings under Parts II, III and V of the SCM Agreement, when addressing subsidies described in Articles 14(a), 14(b), 14(c) and 14(d), relevant provisions of the SCM Agreement shall apply; 
however, if there are special difficulties in that application, the importing WTO Member may then use methodologies for identifying and measuring the subsidy benefit which take into account the possibility that prevailing terms and conditions in China may not always be available as appropriate benchmarks. In applying such methodologies, where practicable, the importing WTO Member should adjust such prevailing terms and conditions before considering the use of terms and conditions prevailing outside China.

(c) The importing WTO Member shall notify methodologies used in accordance with subparagraph (a) to the Committee on Anti-Dumping Practices and shall notify methodologies used in accordance with subparagraph (b) to the Committee on Subsidies and Countervailing Measures.

(d) Once China has established, under the national law of the importing WTO Member, that it is a market economy, the provisions of subparagraph (a) shall be terminated provided that the importing Member's national law contains market economy criteria as of the date of accession. In any event, the provisions of subparagraph (a)(ii) shall expire 15 years after the date of accession. In addition, should China establish, pursuant to the national law of the importing WTO Member, that market economy conditions prevail in a particular industry or sector, the non-market economy provisions of subparagraph (a) shall no longer apply to that industry or sector. ${ }^{34}$

It is clear from the above that the effective waiver by China applies to CVD (paragraph 15(b)) as well as AD actions (paragraph 15(a)). Thus, in AD actions, a "strict comparison with domestic prices or costs in China" will not be required. ${ }^{35}$ The SCM Agreement lacks an explicit bar to determining the "comparable commercial loan" rate through the use of nonnational benchmarks; thus, such benchmarks explicitly may be used pursuant to subparagraph (b). ${ }^{36}$ The only requirements are

\footnotetext{
34 Id. ๆ 15 (emphasis added).

35 Id.

36 SCM Agreement, supra note 3, art. 14.
} 
coverage in national legislation regulations and transparency when such methods are used, ${ }^{37}$ although the use of non-national benchmarks is among those before a panel in the judicial case brought by China. As an additional hurdle, the burden assigned by the Accession Agreement is very much on the foreign producers (in paragraph 15(a)(i)) to "clearly show" that market economy conditions exist. ${ }^{38}$ Otherwise, the investigating authorities are permitted to continue using NME analysis. ${ }^{39}$ While the authorization for use of NME methodology with regard to $A D$ actions (paragraph (a) above) expires after 15 years, the use of NME methodology for subsidy actions carries no such expiration date. $^{40}$

Apart from the accession agreement, the SCM Agreement will likely not assist China or Vietnam to avoid the impact of the NME methodology in either $\mathrm{AD}$ or CVD cases. It is the author's understanding that the United States does not recognize China as a developing country that is subject to the two percent de minimis requirement for subsidy margins, in contrast to the one percent applicable to WTO developing country members under the SCM Agreement. ${ }^{41}$ However, Commerce has not fully rejected the possible treatment of Vietnam as a developing country for this purpose. $^{42}$

\section{B. Vietnam's WTO Accession}

The Vietnam Working Party Report reflects the WTO's experience with China five years earlier, and largely tracks the language in China's WTO Accession Agreement: ${ }^{43}$ The

37 See id.

38 Chinese Accession Agreement, supra note 32, ๆ 15(a)(i).

39 Id. ๆ 15(a)(ii).

40 See id. ๆ15(d).

41 See SCM Agreement, supra note 3, \11.9.

42 Compare PRCB Preliminary CVD Determination, 74 Fed. Reg. at 45820 (recognizing only the margins below one percent as de minimis with U.S. Dep. of Commerce, Issues and Decision Memorandum for Polyethylene Retail Carrier Bags from the Socialist Republic of Vietnam: Final Affirmative Countervailing Duty Determination, Mar. 25, 2010, http://ia.ita.doc.gov/frn/summary/vietnam/2010-73951.pdf (recognizing the argument for margins below two percent to qualify as de minimis but deciding the issue has been mooted)).

43 See, e.g., Vietnam Working Party Report, infra text accompanying note 51. 
Vietnamese Working Party Report provides in pertinent part:

254. Several Members noted that Viet Nam was continuing the process of transition towards a full market economy. Those Members noted that under those circumstances, in the case of imports of Vietnamese origin into a WTO Member, special difficulties could exist in determining cost and price comparability in the context of anti-dumping investigations and countervailing duty investigations. Those Members stated that in such cases, the importing WTO Member might find it necessary to take into account the possibility that a strict comparison with domestic costs and prices in Viet Nam might not always be appropriate.

255. The representative of Viet Nam confirmed that, upon accession, the following would apply-Article VI of the GATT 1994, the Agreement on Implementation of Article VI of the General Agreement on Tariffs and Trade 1994 ("Anti-Dumping Agreement") and the SCM Agreement shall apply in proceedings involving exports from Viet Nam into a WTO Member consistent with the following:

(a) In determining price comparability under Article VI of the GATT 1994 and the Antidumping Agreement, the importing WTO Member shall use either Vietnamese prices or costs for the industry under investigation or a methodology that is not based on a strict comparison with domestic prices or costs in Viet Nam based on the following rules:

(i) If the producers under investigation can clearly show that market economy conditions prevail in the industry producing the like product with regard to the manufacture, production and sale of that product, the importing WTO Member shall use Vietnamese prices or costs for the industry under investigation in determining price comparability;

(ii) The importing WTO Member may use a methodology that is not based on a strict comparison with domestic prices or costs in Viet Nam if the producers under investigation cannot clearly show that market economy conditions prevail in the industry producing the like product with regard to manufacture, production and sale of 
that product.

(b) In proceedings under Parts II, III and V of the SCM Agreement, when addressing subsidies, the relevant provisions of the SCM Agreement shall apply; however, if there are special difficulties in that application, the importing WTO Member may then use alternative methodologies for identifying and measuring the subsidy benefit which take into account the possibility that prevailing terms and conditions in Viet Nam may not be available as appropriate benchmarks.

(c) The importing WTO Member shall notify methodologies used in accordance with subparagraph (a) to the Committee on Anti-Dumping Practices and shall notify methodologies used in accordance with subparagraph (b) to the Committee on Subsidies and Countervailing Measures.

(d) Once Viet Nam has established, under the national law of the importing WTO Member, that it is a market economy, the provisions of subparagraph (a) shall be terminated provided that the importing Member's national law contains market economy criteria as of the date of accession. In any event, the provisions of subparagraph (a)(ii) shall expire on 31 December 2018. In addition, should Viet Nam establish, pursuant to the national law of the importing WTO Member, that market economy conditions prevail in a particular industry or sector, the non-market economy provisions of subparagraph (a) shall no longer apply to that industry or sector.

The Working Party took note of these commitments. ${ }^{44}$

The United States and other WTO Members rely on this language when they use a surrogate country approach in antidumping actions against Vietnam or choose non-Vietnamese "benchmarks" in CVD actions for determining the benefit extended to Vietnamese producers when loans are extended at "preferential" rates and are challenged through national

44 Vietnam Working Party Report, supra note 7, \ 254-55 (emphasis added). 
countervailing duty actions. ${ }^{45}$ The bulk of the language deals with $\mathrm{AD}$ actions, but paragraph 254 explicitly applies to both, and as with China puts the onus on Vietnam and Vietnamese enterprises to demonstrate ME status in a particular industry sector. ${ }^{46}$ With regard to CVD actions, the national authorities have considerable discretion in deciding whether there exist "special circumstances" justifying the use of non-national benchmarks in measuring the benefit of a government subsidy to Vietnamese producers. ${ }^{47}$ With Vietnam, as with China, the expiration date for the use of NME methodology in AD actions (2018) does not apply to CVD actions. ${ }^{48}$ As with Softwood Lumber, discussed infra Part VII, the use of external benchmarks to calculate subsidy benefits is not totally dependent on the Vietnamese and Chinese accession agreements, but is independently authorized in the SCM Agreement. $^{49}$

Nevertheless, it may be feasible, depending on the facts and circumstances of particular cases, for China or Vietnam to challenge the $\mathrm{EU}$ or United States $\mathrm{AD}$ laws in the Dispute Settlement Body "as applied" for failure to use the marketoriented industry approach "if the producers under investigation can clearly show that market economy conditions prevail in the industry producing the like product with regard to the manufacture, production and sale of that product," as set out above. ${ }^{50}$ However, to date no such challenges have been lodged.

By analogy, use of non-national data in CVD actions may also be vulnerable if the independence of relevant agencies from the government can be supported. It also seems reasonable to speculate that the Appellate Body would not permit the United States or other WTO Members to ignore the market-oriented economy exception to NME treatment in $\mathrm{AD}$ actions. If Vietnam could show that some commercial banks operating in Vietnam are free of government controls when interest rates are determined, the use of a pool of foreign bank interest rates for CVD . benefit

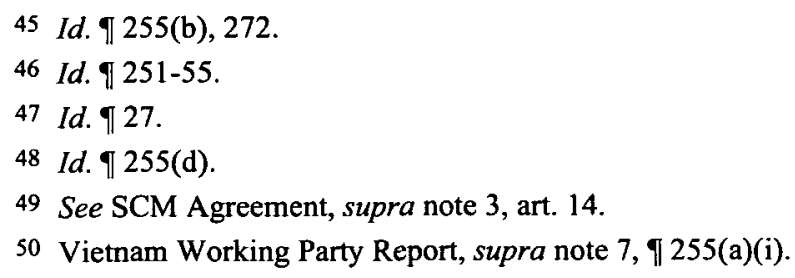


calculations in lieu of Vietnamese commercial bank rates could be challenged. $^{51}$

\section{United States NME Law}

Paragraphs 255(c) and (d) of Vietnam's Working Party Report, quoted above, indicate that where NME methodologies are used by WTO Members those methodologies must be incorporated in national laws and regulations, as well as notified to the WTO. ${ }^{52}$ For example, once Vietnam was to establish "under the national law of the importing WTO Member" that it is a market economy, it must be treated as such. ${ }^{53}$ Under such circumstances, national law is controlling assuming that it is consistent with WTO rules.

\section{A. United States Antidumping Law and NMEs}

Certain aspects of the $\mathrm{AD}$ laws are also relevant to an understanding of the new CVD policy relating to NMEs. United States antidumping law, as it applies to NMEs, defines an NME as "any foreign country that the administering authority [Department of Commerce] determines does not operate on market principles of cost or pricing structures, so that sales of merchandise in such country do not reflect the fair value of the merchandise." on this statute, Commerce in general refuses to calculate dumping margins based on selling prices in the home market, as is the normal approach for ME countries when those prices and related selling costs are determined not by market factors but through central planning. ${ }^{55}$ Instead, Commerce looks to a "surrogate" country, such as India or Bangladesh, where Commerce believes production and selling costs are determined by market forces in a nation or nations at a similar level of development. ${ }^{56}$ The labor, materials and other costs associated with the production and sale of the same or similar products in those countries are effectively

51 At present there is little evidence of the independence of government-owned commercial banks from government influence over the setting of interest rates. See id. ๆ 9-13.

52 See id. at ๆ 255(c)-(d).

$53 I d$. $\uparrow 255(\mathrm{~d})$.

5419 U.S.C. § 1677(18)(A) (2010).

55 See Frozen Fish Fillets, 68 Fed. Reg. at 37116, $37119-20$ (June 23, 2003).

56 See id. at 37120. 
substituted in making the calculations. ${ }^{57}$

The factors considered by Commerce in deciding whether a country should be treated as an NME for antidumping purposes are:

i) the extent to which the currency is convertible;

ii) the extent to which wage rates are determined by free bargaining between labor and management;

iii) the extent to which joint ventures or other investments by foreign firms are permitted;

iv) the extent of government ownership or control of the means of production;

v) the extent of government control over the allocation of resources and over the price and output decisions of enterprises, and

vi) such other factors that [Commerce] considers appropriate. $^{58}$

These factors, particularly the catchall provision (vi), provide the Commerce Department with broad discretion, which Commerce has not been reluctant to utilize, in analyzing NME issues.

The analysis used and conclusions reached by Commerce in its decision to utilize NME methodology for Vietnam in the initial U.S. AD action against Vietnam, Frozen Fish Fillets in 2002, are instructive. Commerce concluded that while Vietnam had made significant progress implementing a variety of reforms, Commerce's analysis indicated that Vietnam had not successfully made the transition to a market economy. ${ }^{59}$ Commerce noted that prices and costs were central to the Department's dumping analysis and calculation of "Normal Value." 60 Commerce determined the following evidence of a market-driven economy was important: "[W]ages are largely determined by free

57 See id.

5819 U.S.C. $\$ 1677(18)(B)(2010)$.

59 See U.S. Dep. of Commerce, Memorandum - Antidumping Duty Investigation of Certain Frozen Fish Fillets from the Socialist Republic of Vietnam - Determination of Market Economy Status, 1, Nov. 8, 2002, http://www.usvtc.org/trade/other/antidumping/catfish/vietnam-market-statusdetermination.pdf.

60 Id. at 7. 
bargaining between labor and management [and] ... various legal reforms have led to the marked and sustained growth of the private sector." ${ }^{\prime 61}$ However, Commerce also determined that:

$[\mathrm{T}]$ he level of government intervention in the economy is still such that prices and costs are not a meaningful measure of value. The Vietnamese currency ... is not fully convertible.... Foreign direct investment is encouraged, but the government still seeks to direct and control it through regulation. Likewise, although prices have been liberalized for the most part, the Government Pricing Committee continues to maintain discretionary control over prices in sectors that extend beyond those typically viewed as natural monopolies. Privatization of SOEs and the state-dominated banking sector has been slow, thereby excluding the private sector from access to resources and insulating the state sector from competition. . . [P]rivate land ownership is not allowed and the government is not initiating a land privatization program. ... [Finally,] [r]ule of law is particularly weak in Vietnam: laws are vague, the judiciary is not independent of the Communist Party, there are few lawyers ... [and] many FIEs have included a provision in their contracts that disputes be handled by the Singapore Court of Arbitration. ${ }^{62}$

There had clearly been substantial progress in Vietnam toward more free market orientation in many of these categories in recent years, particularly foreign law and private land ownership, but full satisfaction of the technical economic requirements is probably some years away.

Notably, many of the steps Vietnam would need to implement to convince Commerce on legal grounds to move it to market economy status for anti-dumping actions are similar to those that Vietnam must take to comply fully with its WTO obligations, and to assure that the current rapid rate of economic development, job creation and eradication of poverty continues. ${ }^{63}$ Interestingly, in

61 Id. at 1-2.

62 Id. at 2, 41.

63 Compare id. (addressing factors the Department of Commerce analyzes in determining ME status) with Vietnam Working Party Report, supra note 7 (outlining methods by which Vietnam planned to address social and economic issues as obligated 
the PRCB Preliminary CVD Determination, Commerce effectively reassessed the statutory NME factors in the Vietnam context, albeit as the basis for rejecting Vietnamese commercial bank loans as a benchmark for calculating the subsidies. ${ }^{64}$ Since the producers had not requested a review of Vietnam's NME status in the AD action, no such review was conducted. ${ }^{65}$

The NME, or market-economy determination, is political as well as economic in the United States. It would likely be politically difficult for the United States to graduate Vietnam before it graduates China. China is some years ahead of Vietnam in developing a vibrant private sector, but China's enormous trade surplus with the United States is such that any action to reduce the level of protection provided by United States antidumping laws against China is unthinkable. Although the order of magnitude of the United States trade deficit is much smaller with Vietnam, which enjoyed a trade surplus with the United States of $\$ 9.2$ billion on total trade of $\$ 15.4$ billion in $2009,{ }^{66}$ the same rationale is applicable to Vietnam. This is reflected in the communique issued by President George Bush and Prime Minister Dung in Washington D.C. in June 2008. ${ }^{67}$ Prime Minister Dung had requested that Vietnam be accorded NME status in antidumping actions. ${ }^{68}$ President Bush simply "acknowledged" the Vietnamese request; he made no promise to study or review the request as was done with other issues raised by Vietnam. ${ }^{69}$

Review and change of practice by the United States regarding NME treatment has often been affected by political and economic considerations. In what is perhaps the most relevant recent action in 2002, the United States agreed that Russia had made the

by its accession to the WTO).

64 See PRCB Preliminary CVD Determination, 74 Fed. Reg. 45811, 45815-16 (Sept. 4, 2009).

65 See generally id. (determining CVDs only).

66 See Office of the United States Trade Representative, U.S.-Vietnam Trade Facts, $\mathrm{http}$ ://www.ustr.gov/countries-regions/southeast-asia-pacific/Vietnam (last visited Oct. 26, 2010).

67 See Press Release, Embassy of the Socialist Republic of Vietnam in the United States of America, Vietnam and US Leaders Meet, Issue Joint Statement, (June 24, 2008), http://www.vietnamembassy-usa.org/news/story.php?d=20080627045153.

68 See id.

69 Id. 
transition to a market economy and accordingly determined that from that time forward Russian costs and prices, and not surrogate country prices, would be used in antidumping actions against Russia. ${ }^{70}$ Because the United States did not follow a practice of bringing CVD actions against NMEs at the time, the U.S. decision to treat Russia as a market economy for $\mathrm{AD}$ purposes also meant that CVD actions could be brought against Russia. ${ }^{71}$ This determination was legally based on the requirements of 19 U.S.C. $\S 1677(18)(\mathrm{B}),{ }^{72}$ discussed in Part IV(A), but undoubtedly had a political overtone, as it took place during a period in which the Bush Administration was strongly seeking better economic and political relations. ${ }^{73}$ Presumably, a decision to afford market economy status to China or Vietnam, if and when it occurs, will also be affected by factors beyond the statutory criteria as well.

Recent actions in Mexico, Australia, and New Zealand also demonstrate that the WTO time periods for applying NME methodology are not immutable. In Mexico, a substantial number of the antidumping duties applied to goods imported from China were terminated or scheduled for termination over a three-year period beginning in October 2008. ${ }^{74}$ These actions were taken in accordance with a bilateral agreement between Mexico and China that concluded in June 2008 and was approved by the Mexican Senate. ${ }^{75}$ However, the affected list of products was incorporated

70 See Andrew L. Stoler, Executive Director, Inst. for Int'l Bus., Econ. and L., Presentation to Forum on WTO System \& Protectionism: Challenges China Faces After WTO Accession: Treatment of China as a Non-Market Economy: Implications for Antidumping and Countervailing Measures and Impact on Chinese Company Operations in the WTO Framework, 5, Dec. 1, 2003,

http://www.iit.adelaide.edu.au/docs/Shanghai\%20Speech.pdf (discussing Russia's transition to ME status under United States practice).

71 See id.

72 See supra text accompanying note 56.

73 See infra note 74.

74 See Adrián Vazquez, Horacio A. López-Portillo \& Veronica Vázquez Bravo, International Law Office, Anti-dumping Duty Agreement Marks New Dawn for Trade with China (Oct. 24, 2008),

$\mathrm{http}: / / \mathrm{www}$.internationallawoffice.com/newsletters/detail.aspx?g=64a54f5d-aec 1-4f02ac93-9828f0b9d461.

75 See Acuerdo entre el Gobierno de los Estados Unidos de Mexico y el Gobierno del la República Popular de China en Materia de Medidas de Remedio Comercial [hereinafter Transition Agreement on Trade Remedies], D.O., Oct. 13, 2008, 
in China's WTO Accession Protocol, which permitted Mexico to depart from WTO rules with respect to restrictions on those products for a period of six years, which expired in $2007 .^{76}$ The accord does not prevent Mexico from continuing to treat China as an NME with regard to other products subject to antidumping investigations for the remainder of the 15 year period specified in China's Accession Protocol, ${ }^{77}$ although such a change in policy is not inconceivable. Nor is there any provision in Mexico's Foreign Trade Law that would prevent Mexico from using NME methodology for antidumping actions against other nations such as Vietnam, but there have been no Mexican unfair trade actions against Vietnam to date. Since Mexico rarely initiates CVD actions, NME treatment by Mexico is not a significant issue for China (or Vietnam).

With Australia (and New Zealand), the decision to revert to market economy status analysis for Vietnam (but not for China) recognized that "Vietnam has made substantial market access commitments under AANZFTA [ASEAN-Australia-New Zealand Free Trade Agreement]." ${ }^{78}$ That determination was not made in isolation but, as the Australian ministry observed, in the context of the FTA negotiations, and applies both to AD and CVD actions. ${ }^{79}$ This suggests, among other things, that it may be useful for Vietnam to continue participating in the U.S. sponsored TransPacific Partnership ("TPP") negotiations of an FTA with Australia, Brunei, Chile, New Zealand, Peru and Singapore. ${ }^{80}$ It is

www.apparelandfootwear.org/letters/acuerdochinmex061308.pdf. The agreement consists of two pages of text and approximately fifty pages of annexes specifying the phase-out of the antidumping duties between 2008 and 2011. See id.

76 See Chinese Accession Agreement, supra note 32, at Annex 7.

77 See id.

78 Australian Press Release, supra note 19.

79 See id.

80 See Amy Tsui, Negotiators Discuss How to Start Drafting Texts for Next Round of TPP Talks in October, Int'l Trade Daily (BNA) (Jun. 16, 2010) available at http://lawlibproxy2.unc.edu:2061/tdln/TDLNWB/split_display.adp?fedfid=17298678\&v name $=$ itdbulallissues $\& \mathrm{fcn}=1 \& \mathrm{wsn}=497411500 \& \mathrm{fn}=1 \overline{7} 298678 \& \mathrm{split}=0 \quad$ (last visited Sept. 9, 2010) (discussing procedures and various issues relating to the TPP). As of June, Vietnam was participating in the negotiations on a provisional basis, and the government had not decided whether to endorse fully the negotiations. A U.S. ASEAN FTA, like that negotiated with the participation of Australia and New Zealand, is not currently politically feasible for the United States because of Burma's membership 
questionable whether the United States would agree to change NME treatment of Vietnam in a multilateral FTA.

Market-oriented Industry. Commerce has the authority to treat a particular industry or enterprise (as distinct from the economy as a whole) in accordance with market principles even if those principles are not applied to other sectors of the economy. This is reflected in the discussion of Vietnam's working party report commitments discussed in Part II. ${ }^{81}$ Commerce requires for purposes of the affected sector a showing that: (1) there is virtually no government involvement in determining prices or production quantities; (2) there is private or collective (rather than full government) ownership; and (3) that all significant inputs are subject to market-determined prices. ${ }^{82}$ This "MOI" treatment has not been granted in NME situations affecting Vietnam, China or any other country in large part because Commerce has not yet promulgated the necessary regulatory procedures for assessing such situations on an enterprise-by-enterprise basis. This contrasts with the EU practice of affording producers of a 2000 case relating to $\mathrm{CD}$ boxes market economy treatment under EC regulations first published in $1999 .^{83}$

Nevertheless, when Vietnamese industries are faced with antidumping actions in the future, it will be well worth providing factual data demonstrating that the particular industry under investigation should be treated under market principles, to the extent such data is persuasive. Eventually this is an area where Commerce could become vulnerable in the WTO's Dispute

in ASEAN, although closer relations in other aspects of international trade are contemplated. See Amy Tsui, U.S., ASEAN Officials Discuss Customs, Financing, Environment Under ASEAN TIFA, INT'L TRADE DAIL (BNA) (May 6, 2010), available at

http://lawlibproxy2.unc.edu:2061/tdln/TDLNWB/split_display.adp?fedfid=17110242\&v name $=$ itdbulallissues \&wsn $=497602500 \&$ searchid $=12330824 \&$ doctypeid $=1 \&$ type $=$ date $\&$ mode $=$ doc\&split $=0 \& s \mathrm{~cm}=$ TDLNWB\&pg $=0$ (last visited Sept. 9, 2010).

81 See supra note 7.

82 U.S. Dept. of Commerce, Anti-Dumping Manual, ch. 10, at 32-33 (2009) available at http://ia.ita.doc.gov/admanual/index.html [hereinafter "Antidumping Manual"]. MOI treatment is codified neither in the law nor the regulations, so its legal status is somewhat unclear from the point of view of U.S. domestic law.

83 See New Market Economy Treatment Rules Set a New Way to Deal with AntiDumping Procedures, Hong Kong Trade Development Council, Jan. 21, 2000, at 1, available at http://info.hktdc.com/alert/eu0002.htm (last viewed June 24, 2010). 
Settlement Body (as well as to domestic court challenge) with regard to Commerce's refusal to find any MOIs in any case involving either China or Vietnam. Although there is an important legal issue of the producers meeting their burden of proof when seeking to demonstrate that their industry follows market economy principles, the adverse results of NME treatment should make this effort a priority in appropriate cases. There is little doubt that in most instances NME treatment results in much higher dumping margins. For example, in an investigation relating to imports of color television receivers from both China and Malaysia concluded in 2004, where essentially identical products were produced in China and Malaysia, the dumping margins for Malaysian firms were de minimis $(0.47 \text { percent })^{84}$ while those for China were predominantly in the twenty-two percent range. ${ }^{85}$ While other factors, including the willingness and ability of the respondents to provide accurate data, may have affected the end results, the difference in results more or less speaks for itself.

Separate rates. The presumptive approach for NME producers in Commerce's $\mathrm{AD}$ investigations is to apply a country-wide dumping margin to all of them on the ground that all are government-controlled. However, if an NME producer can demonstrate that it is not government-controlled, both as a matter of law and in practice, Commerce will apply a separate, individual rate in determining that producer's export price. ${ }^{86}$ (Separate rates do not apply to the determination of normal value, to which export price is compared to determine whether there are dumped sales, i.e., sales in the export market at less than normal value).

Commerce has developed a "separate rates" test for determining when such separate treatment is warranted. ${ }^{87}$ This

84 Notice of Amended Final Determination of Sales at Not Less Than Fair Value: Certain Color Television Receivers from Malaysia, 69 Fed. Reg. 25561, 25564 (May 7, 2004).

85 Antidumping Duty Order: Certain Color Television Receivers from the People's Republic of China, 69 Fed. Reg. 31347-31348 (Jun. 3, 2004); Final Determination of Sales at Less Than Fair Value and Negative Final Determination of Critical Circumstances: Certain Color Television Receivers from the People's Republic of China, 69 Fed. Reg. 20594, 20597 (Apr. 16, 2004).

86 Antidumping Manual, supra note 82, at 3-6.

87 Antidumping Methodologies in Proceedings Involving Non-Market Economy Countries: Surrogate Country Selection and Separate Rates, 72 Fed. Reg. 13246, 13247- 
test focuses whether the company is a de jure or de facto government-controlled entity. ${ }^{88}$ A lack of de jure governmental control is indicated by (a) an absence of restrictions on its business operations and exports; (b) any governmental legislation that illustrates a lack of governmental control (for example, privatization legislation); and (c) other governmental actions that indicate that the company is not controlled by the government. ${ }^{89}$ Whether the NME government exercises de facto control is indicated by (a) whether the company's export prices are set by the government, (b) whether the company is free to negotiate and sign contracts without government involvement or approval, (c) whether the company may make autonomous decisions with regard to management selection, and (d) whether the company retains its export sales revenue and makes its own decisions regarding how to use its profits or finance its losses. ${ }^{90}$

Separate rates were granted to many Vietnamese producers in Frozen Fish Fillets and Shrimp and, as discussed in Part VI(B), in the preliminary determination in $P R C B s,{ }^{91}$ separate rates have also been granted to certain Chinese producers in U.S. AD actions against China on a regular basis. This approach provides cooperating and qualifying respondents an opportunity to substantially reduce the uncertainties and inaccuracies on the export price side of the equation, since by definition such respondents have control over the prices at which they market their products abroad.

\section{B. Application of U.S. CVD Laws to NMEs}

A closely-related matter is treatment of Vietnam under the U.S. countervailing duty laws, directed at foreign imports that

13248 (March 21, 2007) [hereinafter Surrogate Country Selection]; Notice of Final Determination of Sales at Less Than Fair Value: Bicycles from the People's Republic of China, 61 Fed. Reg. 19026, 19027 (Apr. 30, 1996).

88 See infra note 89.

89 Antidumping Methodologies in Proceedings Involving Non-Market Economy Countries: Surrogate Country Selection and Separate Rates, 72 Fed. Reg. 13246, 13248 (Mar. 21, 2007).

$90 \mathrm{Id}$.

91 See PRCB Preliminary AD Determination, 74 Fed. Reg. 45811, at 56816 (Sept. $4,2009)$. 
benefit from actionable government subsidies. ${ }^{92}$ Here, the law itself is silent on treatment of NMEs. In effect, Commerce has discretion either to refrain from bringing CVD actions against NMEs, as was the practice from the mid-1980s until 2006, or to bring such actions as is current practice. Until 2006, Commerce took the position that under U.S. law, countervailing duty actions were not intended to apply to NMEs, a position that had been upheld by U.S. courts. ${ }^{93}$ The essence of the Commerce rationale was that it was impossible to determine the extent to which a "bounty or grant" (subsidy) existed because the government rather than market forces determined the costs of various inputs used in the production of goods, and subsidies could not be separated from other government directives and controls. Under such circumstances, a NME country risked a methodology for determining the existing of dumping that tended to exaggerate actual dumping margins, but was essentially insulated from CVD actions designed to offset government subsidies.

In 2006, Commerce changed its policy and initiated a CVD investigation against coated paper from China. ${ }^{94}$ While that particular case was ultimately dismissed for lack of a demonstration of material injury to U.S. producers, countervailing duties (at rates of up to 615 percent) were applied to imports of line pipe into the United States in a 2008 determination. ${ }^{95}$ At least nine CVD duty orders against China have been issued with additional orders pending before Commerce. ${ }^{96}$ Also, Commerce is being strongly urged by Congress to make the new NME CVD policy applicable to all NMEs. ${ }^{97}$ China has challenged various

92 World Trade Organization, Agreement on Subsidies and Countervailing Measures, Part V [hereinafter SCM Agreement].

93 See Georgetown Steel Corp. v. United States, 801 F.2d 1308, 1309 (Fed. Cir. 1986).

94 Notice of Investigation of Countervailing Duty Investigations: Coated Free Sheet Paper from the People's Republic of China, Indonesia and the Republic of Korea, 71 Fed. Reg. 68546 (Nov. 27, 2006).

95 ITC Affirmative Injury Finding in Pipe Case Is First Time CVD Duties to Apply to China, 25 INT'L TRADE REP. (BNA) 960 (June 26, 2008).

96 See Commerce Dept., AD/CVD Orders in Place as of May 10, 2010, available at http://info.usitc.gov/oinv/sunset.nsf/0a915ada53e192cd8525661a0073de7d/96daf5a6c0c $5290985256 \mathrm{a} 0 \mathrm{a} 004 \mathrm{dee} 7 \mathrm{~d} / \mathrm{SFILE} /$ orders\%20May\%2010\%202010.xls (last visited Oct. 28,2010 ).

97 Amy Tusi, Commerce Announces Significant Shift, Applies CVD Law in 
aspects of the United States' imposition of $\mathrm{AD}$ and CVDs against China in the WTO, as applied in specific cases. ${ }^{98}$

There are obvious conceptual inconsistencies between the use of NME methodology in an anti-dumping case (relying on surrogates because various input costs are not based on marketdetermined prices) and the assertion that "private industry now dominates many sectors of the Chinese economy" with a much smaller role of government planners so that government subsidies can be accurately measured. Although, to some extent Commerce relies on surrogates to determine subsidy benchmarks as well. ${ }^{99}$ However, Commerce's requirement that "significantly all" factor input prices be market driven is ambiguous and may guarantee that no such industries will be found. ${ }^{100}$ Consequently, a strict marketoriented industry test as applied by Commerce virtually guarantees that a market orientated industry will not be found in $\mathrm{AD}$ actions against NMEs. ${ }^{101}$ Logically, under such circumstances, CVD law should not apply because of the lack of market determination of the price of inputs that might be considered government subsidies. This disconnect is illustrated by the fact that some of the factors cited justifying subjecting Vietnam to CVD laws directly in PCRBs in 2009 despite the fact that Vietnam is now considered a mixed economy in contrast with Commerce's NME determination in the $\mathrm{AD}$ proceeding concerning Frozen Fish Fillets in 2002.

A more immediate threat to Commerce's methodology relates to allegations that by imposing both AD and CVDs against NMEs,

Chinese Paper Case, 24 INT'L Trade ReP. (BNA) 495, 498 (Apr. 5, 2007).

98 United States - Definitive Anti-Dumping and Countervailing Duties on Certain Products from China, WT/DS379/2, Dec. 12, 2008 [hereinafter US - AD/CVDs China].

99 Tatelman B. Todd, United States' Trade Remedy Law and NMEs: a legal overview, CRS Report for Congress, Order Code RL 33976, April 23, 2007, p.12, available at $w$ ww.policyarchive.org/handle/10207/bitstreams/3231.pdf.

100 Id. at 10. (citing Lawrence J. Bogard \& Lind C. Menghetti, The Treatment of NMEs under the US AD and CVD law: A petitioner's perspective, PLI Corp. Law and Practice Course Handbook, Series No. 789, 6-7 (1992), available at www.policyarchive.org/handle/10207/bitstreams/3231.pdf).

101 Joseph A. Laroski, NMEs: A love story NME and market economy status under US AD law, 30 LAW \& POL'Y INT'L BUS. 369, 396 (1999) (citing Robert H. Lantz, The Search for Consistency: Treatment of NMEs in Transition under the US AD and CVD law, 10 AM. U. J. INT'L L. \& POL'Y 993, 999 (1995)). 
Commerce is double-counting in contravention of GATT $1994 .{ }^{102}$ The GATT provides, "No product of the territory of any contracting party imported into the territory of any other contracting party shall be subject to both anti-dumping and countervailing duties to compensate for the same situation of dumping or export subsidization." 103 In theory at least, there is no potential double-counting with regard to domestic subsidies since a domestic subsidy provided to an enterprise should benefit both domestic and export sales in the same manner. ${ }^{104}$ Commerce generally avoids the double-counting problem in parallel AD/CVD actions against market economy nations by adjusting for the possible overlap of a benefit calculated as a result of a government export subsidy and sales at less than fair value (dumping) to the extent the dumping margins result from that same situation with a setoff in appropriate circumstances. ${ }^{105}$ The problem is more complex in an NME situation where the distinctions between dumping and subsidization on exported goods are more difficult to distinguish, ${ }^{106}$ and where the magnitude of dumping and the amount of benefit are not based on actual prices and commercial loan rates in the NME home market but on surrogate values (dumping) and non-national benchmarks (subsidies), often based on entirely different surrogate countries.

Because of the likelihood of double-counting, the U.S. Court of International Trade ("CIT") recently reversed and remanded Commerce's parallel AD/CVD findings against China. ${ }^{107}$ The court reasoned that unlike the situation in which the dumping duties in parallel $\mathrm{AD}$ and CVD proceedings in a market economy are calculated based on normal value and export price, in NME actions, the export price is not being compared with the price of

102 See Le \& Mai, infra note 243.

103 GATT 1947, art. VI.5.

104 Typically, the benefit from a domestic subsidy is allocated by Commerce overall production, whether it is exported or sold domestically. An export subsidy by definition benefits exports alone. See SCM Agreement, art. 3, supra note 92.

105 See 19 U.S.C. $\$ 1677 \mathrm{a}(\mathrm{c})(1)(\mathrm{C})(2000)$.

106 See Ross Denton, The NME rules of the EC's AD and Countervailing Duty Legislation, 36 INT'L \& COMP. L. Q. 198, 236 (1987) (discussing the double-counting problem).

107 GPX Intern. Tire Corp. v. U.S., 645 F. Supp. 2d 1231, 1251 (Ct. Int'l Trade 2009). 
the good in the domestic market, but rather, in a surrogate country market which is presumably subsidy-free. ${ }^{108}$ Without adjustment the court reasoned, such a situation could result in doublecounting. ${ }^{109}$ In the initial CIT proceeding, Commerce conceded that it had not yet developed the necessary procedures for analyzing such requests from individual enterprises. Judge Restani found "that Commerce's failure to address GPX's request for MOE status because it had no policies, procedures, or standards for evaluating MOE status was arbitrary and capricious and unsupported by substantial evidence." 110 The Court, mindful as well of the conceptual inconsistency, held that "[i]f Commerce now seeks to impose CVD remedies on the products of NME countries as well [as $\mathrm{AD}$ duties], Commerce must apply methodologies that make such parallel remedies reasonable, including methodologies that will make it unlikely that double counting will occur." 11

In the final CIT decision after remand Commerce is effectively foreclosed from imposing CVDs on NMEs barring a change in methodology, confirming what Judge Restani said in the initial decision. ${ }^{112}$ If the CIT decision is ultimately upheld by the U.S. Court of Appeals for the Federal Circuit ("CAFC"), some modification of Commerce's methodology in numerous simultaneous $\mathrm{AD} / \mathrm{CVD}$ proceedings against China and Vietnam is inevitable if Commerce intends to continue bringing CVD actions against China while maintaining China's status as an NME for AD actions. Whether Commerce can promptly develop procedures for analyzing requests for individual market-oriented industry treatment so that the firm could be analyzed under market economy procedures, a deficiency that was also challenged in GPX Tire, ${ }^{13}$ remains to be seen.

China is also challenging the double-counting in an "as such"

108 See id. at 1245.

109 See id. at 1234-35.

$110 \mathrm{Id}$. at 1247.

111 Id. at 1243.

112 GPX Intern. Tire Corp. v. U.S., Consol. Ct. No. 08-00285, Slip. Op. 10-84 (Ct. Int'l Trade Aug. 4, 2010).

113 GPX Tire, 645 F.Supp.2d. at 1246. 
claim before the WTO, ${ }^{114}$ which may provide alternative relief even if the CAFC ultimately reverses the CIT. Even if Commerce prevails in the U.S. courts, it may be less successful at the WTO, meaning that an articulation of procedures will inevitably be needed.

The pursuit of CVD cases with the use of surrogate country methodology (particularly for determining "benchmark" rates) is permitted by the WTO's SCM Agreement, ${ }^{115}$ and under at least one Appellate Body ruling, in Softwood Lumber, as discussed in Part VII. Nor is there any apparent WTO bar to simultaneous $\mathrm{AD} / \mathrm{CVD}$ actions against NMEs, despite the economic inconsistency of such actions. Rather it is the double-counting problem that makes Commerce most vulnerable to challenge in such situations.

\section{U.S. NME CVD Methodology and Practice - China}

This article does not discuss NME CVD practice with regard to China in detail. However, given the parallel approach to Vietnam, a basic understanding of the development of Commerce's policy regarding China is instructive.

From 1984 until the mid-1990s, Commerce generally followed a practice of not initiating CVD actions against NMEs, based on the Georgetown Steel case. However, in the so-called Georgetown Steel memorandum in 2007, ${ }^{116}$ Commerce justified its change in practice with respect to China. In the memorandum, Commerce analyzed the rationale for excluding NMEs from CVD actions in the 1980s (continuing into the 1990s). Commerce noted that in 1984 it had concluded that:

[T] he nature of the Soviet-style economies in the mid 1980s made it impossible for the Department to apply the

CVD law. To determine that a countervailable subsidy had

114 US - AD/CVDs - China, supra note 98, at 7-8.

115 See SCM Agreement, art. 14(d).

116 Memorandum for David M. Spooner, CVD Investigation of Coated Free Sheet Paper from the People's Republic of China - Whether the Analytical Elements of the Georgetown Steel Opinion are Applicable to China's Present-Day Economy (Mar. 29, 2007) [hereinafter China DVD Applicability Memo] available at http://ia.ita.doc.gov/download/nme-sep-rates/prc-cfsp/china-cfs-georgetownapplicability.pdf. 
been bestowed, the Department needed to establish that: (a) the NME government had bestowed a "bounty or grant" on a producer; and (b) that the bounty or grant was specific. The Soviet-style economies at the time made it impossible to apply these criteria because they were so integrated as to constitute, in essence, one large entity. In such a situation, subsidies could not be separated out from the amalgam of government directives and controls. ${ }^{117}$

However, China (in 2007) is different:

The current nature of China's economy does not create these obstacles to applying the statute. As noted above, private industry now dominates many sectors of the Chinese economy, and entrepreneurship is flourishing. Foreign trading rights have been given to over 200,000 firms. Many business entities in present-day China are generally free to direct most aspects of their operations, and to respond to (albeit limited) market forces. The role of central planners is vastly smaller... Given these developments, we believe that it is possible to determine whether the PRC Government has bestowed a benefit upon a Chinese producer (i.e., the subsidy can be identified and measured) and whether any such benefit is specific. Because we are capable of applying the necessary criteria in the CVD law, the Department's policy that gave rise to the Georgetown Steel litigation does not prevent us from concluding that the PRC Government has bestowed a countervailable subsidy upon a Chinese producer. ${ }^{11}$

Thus, Commerce determined that it had sufficient discretion to apply CVDs to NMEs under applicable U.S. law (although it was not required to do so), and that it was appropriate to use the CVD laws against China, despite its NME status for AD purposes. This approach has been followed in subsequent cases against China. ${ }^{19}$ Commerce reached similar conclusions when it conducted an analysis of Vietnam in PRCBs and is following the same general approach to CVD cases as with China. ${ }^{120}$

\footnotetext{
117 Id. at 10.

118 Id.

119 Id.

120 See infra Part V.
} 
Judging by the actions brought against China, the methodology used by Commerce to determine whether a benefit is conferred by a particular subsidy uses a mix of methodologies applied to market economies and special rules designed for NMEs, in contrast to its all or nothing approach in AD actions. For example, in Coated Free Sheet Paper, ${ }^{121}$ Commerce calculated the benefit for certain tax reductions provided to producers by comparing the normal tax rate with the preferential tax rate, and treating the difference as the benefit, as would have occurred in a normal ME CVD analysis. ${ }^{122}$

However, in certain areas, Commerce, as authorized in the WTO Accession Agreement, rejected the use of Chinese benchmarks because of alleged Chinese intervention in the markets. ${ }^{123}$ For example, in determining the benefit for allegedly preferential loan rates afforded to producers or exporters, Commerce determined that there was no commercial, nonpreferential interest rate available in China. ${ }^{124}$ Instead, to create a benchmark rate, Commerce analyzed the commercial interest rates in thirty-three developing countries with per capita GDPs similar to China's, with the composite interest rate being determined to be 7.56 percent (2005). ${ }^{125}$ The concept of rejecting national benchmark rates is not confined to market economies, although it is explicit in China's WTO Protocol of Accession. ${ }^{126}$ In its analysis of alleged Canadian subsidies of softwood lumber, Commerce rejected the use of Canadian commercial rates for the sale of standing timber, and relied instead on timber charges in the United States as the benchmark. ${ }^{127}$

In Coated Free Sheet Paper, Commerce also considered as subsidies various Chinese Government policies, such as providing

121 U.S. Dept. of Commerce, Coated Free Sheet Paper from the People's Republic of China: Final Affirmative Countervailing Duty Determination, 72 Fed. Reg. 60645 (Oct. 25, 2007); Issues and Decision Memorandum for the Final Determination in the Countervailing Duty Investigation of Coated Free Sheet from the People's Republic of China (Oct. 17, 2007) [hereinafter "Coated Free Sheet Paper Decision Memorandum"], available at http://ia.ita.doc.gov/fm/summary/prc/E7-21046-1.pdf.

122 Id. at 11.

123 Id. at 67.

124 See id.

125 Id. at 67.

126 See supra note 32, at Part II.A.

127 See supra note 32, at Part VI. 
preferential financing for the paper industry through various mechanisms. ${ }^{128}$ Commerce concluded that this type of provision "explicitly detail[s] an active role for the State in implementing industrial policies, whether though industrial policy coordination or through the guidance of financial resources towards those industries that the State favors (such as large integrated paper companies) and away from those the state considers outmoded." 129

The investigation also gave particular attention to special benefits conferred on foreign invested enterprises (FIEs), which receive tax subsidies under Chinese law according to Commerce. $^{130}$ Despite the fact that FIEs in China cut broadly across industry sectors, Commerce determined that the tax subsidies they receive, despite their broad applicability and transparent nature, are specific under the SCM Agreement, and are thus countervailable. ${ }^{131}$

In dealing with upstream subsidies, in this case pulp log producers, Commerce essentially followed its practice of attributing such subsidies to downstream producers (in this case of paper), as it has in similar cases involving market economies such as Indonesia. ${ }^{132}$

The general approach of Coated Free Sheet Paper has been followed by Commerce in other Chinese cases, as in the September 2009 preliminary determination and December 2009 final determination in Oil Country Tubular Goods. ${ }^{133}$ There,

\footnotetext{
128 Coated Free Sheet Paper Decision Memorandum, supra note 121, at 54.

129 Id. at 53.

$130 \mathrm{Id}$. at 85 .

131 Id.

132 Id. at 98.

133 See U.S. Dept. of Commerce, Certain Oil Country Tubular Goods from the People's Republic of China: Preliminary Affirmative Countervailing Duty Determination, Preliminary Negative Critical Circumstances Determination, 74 Fed. Reg. 47210 (Sept. 15, 2009) [hereinafter Preliminary OCTG]; U.S. Dept. of Commerce, Certain Oil Country Tubular Goods from the People's Republic of China: Final Affirmative Countervailing Duty Determination, 74 Fed. Reg. 64045 (Dec. 7, 2009) [hereinafter Final OCTG]; Issues and Decision Memorandum for the Final Determination in the Countervailing Duty Investigation of Certain Oil County Tubular Goods ("OCTG") from the People's Republic of China, at 103 (Nov. 23, 2009) [hereinafter Decision Memorandum OCTG], available at http://ia.ita.doc.gov/frn/summary/PRC/E9-28779-1.pdf.
} 
Commerce reiterated its policy of applying the CVD laws to China and again used a non-Chinese interest rate derived from marketbased interest rates observed in a pool of lower-middle income countries, also citing the methodology used in Softwood Lumber. ${ }^{134}$ As stated by Commerce in the Decision Memorandum, "The Department continues to find that loan benchmarks must be market-based and that Chinese interest rates are not reliable as benchmarks because of the pervasiveness of the GOC's intervention in the banking sector."135

\section{U.S. Methodology and Practice - Vietnam: Polyethylene Retail Carrier Bags (PRCBs)}

PRCBs is important because it is to date (July 2010) the only proceeding seeking the imposition of CVDs against Vietnamese producers, and just the third seeking antidumping duties. ${ }^{136}$ The $\mathrm{AD}$ proceedings broke no new ground, in significant part because Commerce was not required to review whether the Vietnamese producers constitute a market-oriented industry, or re-evaluate its application of NME criteria to Vietnam for the first time since Frozen Fish Fillets. Once a non-market economy determination is made it "remain[s] in effect until revoked," and no effort was made to revoke that status in PRCBs. ${ }^{137}$ While the subsidy rates were low, ranging from 0.20 percent to 4.24 percent for the three firms specifically reviewed, and a rate of 2.97 percent applied to other manufacturers in the preliminary determination ${ }^{138}$ and 0.44 percent to 5.28 percent in the final, ${ }^{139}$ and the import volume less than one percent of U.S. imports from Vietnam (\$79 million). ${ }^{140}$

134 See Preliminary OCTG, supra note 136 , at $47212,47216$.

135 See Decision Memorandum OCTG, supra note 136, at 103.

136 Petition filed by King \& Spaulding, Mar. 31, 2009.

137 See "PRCB Preliminary AD Determination," supra note 9, at 56815; Memorandum for Ronald K, Lorentzen, Countervailing Duty Investigation of Polyethylene Retail Carrier Bags from the Socialist Republic of Vietnam - Whether the Countervailing Duty Law is Applicable to Vietnam's Present Day Economy (copy on file with author) [hereinafter Vietnam CVD Applicability Memo] (asserting that the AD NME status issue is "separate and distinct" and that NME status will remain in effect for Vietnam until a review is requested).

138 PRCB Preliminary CVD Determination, supra note 9, at 45820.

139 PRCB Final CVD Determination, supra note 10, at 16430.

140 See U.S. Dept. of Commerce, Fact Sheet, Commerce Preliminarily Finds 
Still, the precedent will likely be applied to more economically important proceedings in the future.

A. PRCBs - CVD Action

\section{Applying CVD Law to Vietnam}

Since Commerce had not initiated CVD actions against Vietnam (unlike China) in the past, Commerce was effectively required in PCRBs to determine whether U.S. CVD law applies to Vietnam. ${ }^{141}$ In this case, as in initial CVD actions against China, the U.S. petitioners argued that the conditions that led Commerce to decline to initiate CVD investigations against the Soviet Union over 20 years ago in Georgetown Steel, but to abandon with regard to China in 2006 , are analogously applicable to Vietnam. ${ }^{142}$ As the notice in PCRBs observes:

The petitioners argue that the Vietnamese economy, like China's economy, is substantially different from the Soviet-style economy investigated in Georgetown Steel and that the Department should not have any special difficulties in the identification and valuation of subsidies involving a non-market economy like Vietnam. Finally, the petitioners contend that Vietnam's economy significantly mirrors China's present-day economy and is at least as different from the Soviet-style economy at issue in Georgetown Steel, as China's economy was found to be in 2007. The petitioners also argue that Vietnam's accession to the World Trade Organization (WTO) allows the Department to apply countervailing duties on imports from that country. The WTO Subsidies and Countervailing Measures Agreement (SCM Agreement), similar to U.S. law, permits the imposition of countervailing duties on subsidized imports from member

\footnotetext{
Subsidization of Polyethylene Retail Carrier Bags from the Socialist Republic of Vietnam, at 9 (Aug. 31, 2009), available at

http://ia.ita.doc.gov/download/factsheets/factsheet-vietnam-prcb-cvd-prelim-083109.pdf.

141 See U.S. Dept. of Commerce, Polyethylene Retail Carrier Bags from the Socialist Republic of Vietnam: Initiation of Countervailing Duty Investigation and Request for Public Comment on the Application of the Countervailing Duty Law to Imports from the Socialist Republic of Vietnam, 74 Fed. Reg. 19064 (Apr. 27, 2009).

142 See id. at 19067.
} 
countries and nowhere exempts non-market economy imports from being subject to the provisions of the SCM Agreement. As Vietnam agreed to the SCM Agreement and other WTO provisions on the use of subsidies, the petitioners argue Vietnam should be subject to the same disciplines as all other WTO members. ${ }^{143}$

Petitioners alleged as well that various Vietnamese government programs constituted countervailable subsidies. ${ }^{144}$ These included preferential lending for exporters; preferential lending for the plastics industry; export promotion programs, export bonus program; new product development program; various income tax benefits for exporters, FIEs, FIEs operating in encouraged industries and various import tax and VAT exemption programs. ${ }^{145}$ All of these were addressed in the preliminary determination.

In the Preliminary determination of subsidies (and again in the final), Commerce essentially agreed with the petitioners, but only after a relatively thorough analysis of Vietnam's present-day economy, with emphasis on the increased economic power of domestic private and foreign invested enterprises while the number of state-owned enterprises ("SOEs") had been reduced from 12,000 to about 1,800 and correspondingly reduced employment and total economic output. ${ }^{146}$ Commerce also noted significant reforms in SOEs, but with limits on privatization suggesting that the SOE sector will continue indefinitely. Among other factors cited by Commerce as justification for applying CVD laws to Vietnam were the partial deregulation of prices and production inputs and increased participation of Vietnam in the world economy. ${ }^{147}$

143 Id.

144 See id. at 19066.

$145 \mathrm{Id}$. at 19066-67.

146 Vietnam CVD Applicability Memo, supra note 137, at 4. Here, as with the China CVD Applicability Memo, supra note 60, Commerce has made a practice of addressing such issues separately from the formal preliminary and final determinations; see, e.g., Issues and Decision Memorandum for Polyethylene Retail Carrier Bags from the Socialist Republic of Vietnam: Final Affirmative Countervailing Duty Determination, at 13 (Mar. 25, 2010) [hereinafter PCRB Final CVD Decision Memo], available at http://ia.ita.doc.gov/frn/summary/VIETNAM/2010-7395-1.pdf.

147 Vietnam CVD Applicability Memo, supra note 80, at 8-9. 
The result was a conclusion that Vietnam's economic space today is a mixed landscape of public, private and foreign ownership. The non-State sector has grown rapidly and accounts for an increasing share of production, investment employment and trade, although SOEs continue to play a significant role in the economy. However, the economic reforms are incomplete and structural and institutional legacy problems remain. ${ }^{148}$

While the conclusions are to a considerable degree supported by Commerce's careful analysis, they appear to reflect as well an effort to provide a colourable basis for applying CVD laws while at the same time avoiding to the extent possible erosion of the rationale for treating Vietnam as an NME in antidumping cases.

This determination to apply the CVD laws to Vietnam was unchanged in the final CVD determination, with Commerce noting Congressional support for Commerce's decision to apply the CVD laws in a situation parallel to China's, and concluding that "The clear implication of these Congressional statements is that the CVD law can be applicable to NMEs" and that "these [Congressional] statements contemplate that the Department's application of the CVD law to NMEs would take place simultaneously with the continued application of the Department's NME antidumping methodology."

\section{Key Issues in the CVD Determination}

In its preliminary and final determinations, Commerce for the most part followed the same approach as in CVD actions against China, including that in Coated Free Sheet Paper. Thus, Commerce decided that it would apply CVD law to Vietnam only as of Vietnam's accession to the WTO in January 2007, on the ground that such limitation was "appropriate and administratively desirable" and because Commerce concluded that Vietnam's accession agreement "contemplate[s] application of the CVD law." "150 Commerce also found general support for bringing CVD actions in the discussion of benchmarks in Vietnam's working

148 Id. at 11.

149 "PCRB Final CVD Decision Memo," supra note 10, at 14. Facts available were used for one participant, API, for lack of cooperation.

150 "PRCB Preliminary CVD Determination," supra note 9, at 45814. 
party report, as quoted above. ${ }^{151}$ This timing issue did not arise with regard to China, since China became a WTO Member nearly five years before Commerce brought the first CVD action against China, whereas Vietnam had been a member for only 15 months before Commerce brought its first action.

As in Coated Free Sheet Paper, the choice of "benchmark" rates for calculating the benefit from government loans was a central issue in Polyethylene Retail Carrier Bags. The general "basket" approach was similar but only after Commerce extensively reviewed Vietnam's banking sector to justify rejecting Vietnamese lending rates as market-based and corresponding use of an external benchmark. ${ }^{152}$ In the memorandum, Commerce reviewed various legal and banking reforms and for banks "substantial flexibility in setting interest rates since 2002, although such flexibility is limited ...." Perhaps inevitably, Commerce found it appropriate to begin its analysis of the banking system with its non-market economy status determination in Frozen Fish Fillets in 2002, setting forth its view of the changes in the ensuing seven years. However, despite the changes, Commerce found, inter alia, many "institutional weaknesses" as well as lack of transparency and continued de facto benefits enjoyed by stateowned commercial banks, and observed that the reforms "continue to lag and remain incomplete." 154

In deciding to use a commercial benchmark, Commerce again went beyond the borders of Vietnam. For dong-denominated loans, Commerce put together a basket of currencies relying with some exceptions on the World Bank's list of 54 "lower middle income" countries. ${ }^{155}$ In doing so, Commerce preliminarily rejected both the "low income" countries for a variety of reasons,

151 See id.

152 Memorandum for Ronald K. Lorentzen, Countervailing Duty Investigation of Polyethylene Retail Carrier Bags from the Socialist Republic of Vietnam - A Review of Vietnam's Banking Sector (Aug. 28, 2009), at 9 [hereinafter Vietnam Banking Sector Memo].

153 Id. at 5 .

154 Id. at 7.

155 Memorandum through Mark Hoadley, Countervailing Duty Investigation of Polyethylene Retail Carrier Bags from the Socialist Republic of Vietnam - Preliminary Determination Calculations Loan Benchmark Analysis (Aug. 28, 2009), at 9 [hereinafter Vietnam Loan Benchmark Memo]. 
even though Vietnam with its $\$ 890$ per capita gross national income ("GNI") is near the boundary between low income and lower middle income, with the latter showing a per capita GNI of $\$ 975$. $^{156}$ Once adjustments were made to exclude any NMEs in the World Bank grouping, and others that had not reported local currency lending rates, Commerce used a regression analysis to determine a rate of 7.385 percent for 2007 and 4.165 percent for 2008 as the applicable benchmark. ${ }^{157}$ For dollar-denominated loans, Commerce used LIBOR rates with some adjustments. ${ }^{158}$

The determination that the plastics industry in Vietnam receives preferential lending was based on an analysis of "targeted" actions taken by state-owned commercial banks ("SOCBs") and coordinated by the State Bank of Vietnam rather than on more direct government support. Commerce determined that "the merchandise under investigation is part of a state targeted, or encouraged, industry or project, and that there is evidence that loans from SOCBs are a designated means for developing that industry or project," despite the lack of a "single policy document directing preferential lending...."159 Since SOCBs were determined to be public entities on the basis of their majority ownership by the government, the loans provided by SOCBs were considered government financial contributions. ${ }^{160}$ Because the plastics industry was allegedly targeted, the loans were considered specific under U.S. CVD laws in the preliminary determination. ${ }^{161}$ However, in the final determination Commerce concluded that plastics industry subsidized loans were not available to PCRB products. ${ }^{162}$

Commerce's calculation of whether land was provided to PRCB manufacturers at preferential rates so as to afford a benefit was complicated by its conclusion that "the purchase of land-use rights [in Vietnam] is not conducted in accordance with market 2009).

156 PRCB Preliminary CVD Determination, 74 Fed. Reg. 45811, 45815 (Sept. 4,

157 Vietnam Loan Benchmark Memo, supra note 155, at 2.

158 PRCB Preliminary CVD Determination, 74 Fed. Reg. at 45815.

159 Id. at $45816-17$.

160 Id. at 45817.

16119 U.S.C. $\S 1677(5 A)(D)(i)$.

162 PCRB Final CVD Decision Memo, supra note 10, at 18. 
principles." ${ }^{163}$ This conclusion was based in part on the observation that the land leased by the government to intermediaries, and then subleased by intermediaries to producers, had been expropriated from farming interests and the prices charged by the government. The intermediaries "are based on low-priced agricultural land tariffs determined without reference to what is allegedly the most market-oriented portion of the commercial land market" or by lease prices set by brokers for subleasing tenants. ${ }^{164}$

Accordingly, and again using a methodology borrowed from CVD actions against China, ${ }^{165}$ Commerce used as an external benchmark "comparable market-based prices in a country at a comparable level of economic development that is within the geographic vicinity of Vietnam."166 However, Commerce rejected the use of Thailand and the Philippines as benchmarks (as with China) because of their relatively high per capital GNIs, $\$ 2,840$ and $\$ 1,890$ respectively. ${ }^{167}$ Rather, Commerce relied on rental data from a country with a per capita GNI more similar to Vietnam's. Commerce chose to use average rental rates for two cities in India, Pune and Bangalore, noting that the per capita GNI for India is $\$ 1,070$, compared to $\$ 890$ in Vietnam, even though the population density in the Philippines was said to be a closer match to Ho Chi Minh City, Vietnam than with the two Indian cities. ${ }^{168}$ Using the Indian (Pune) rates as the benchmark, Commerce found a land rental subsidy of 3.86 percent. ${ }^{169}$

Commerce also countervailed one producer, Fotai, which as a Foreign Invested Enterprise ("FIEs") received certain income tax preferences from the Vietnamese government that were limited to FIEs. Here, Commerce ultimately calculated the amount of the subsidy ( 0.21 percent) based on a comparison of the normal tax

163 PRCB Preliminary CVD Determination, supra note 9, 74 Fed Reg. at 45815.

164 PCRB Final CVD Decision Memo, supra note 10, at 27.

165 See Preliminary - OCTG, supra note 133, at 47222 (determining to use Thailand as a benchmark to address whether Chinese received benefits regarding land use rights).

166 PRCB Preliminary CVD Determination, supra note 9, at 45815.

167 Id. at 45816.

168 Id.

169 Id. at 45818. 
rate with the preferential tax rate. ${ }^{170}$ Another producer, Chin Shen, was also determined to benefit from other tax reduction programs. ${ }^{171}$ Finally, Commerce determined subsidies of 2.17 percent and 0.02 percent for Fotai based on exemption of raw materials, certain imports of spare parts, and accessories from import duties if the importer is located in an industrial zone. ${ }^{172}$

Commerce determined that the remission of the value added tax on equipment at the time of importation was not countervailable, and that a number of export promotion and tax benefit programs were not actionable because the respondents had not used them. ${ }^{173}$

Whether Vietnam is to be treated as a developing country for purposes of Article 27 of the SCM agreement, thus eligible to receive a 2 percent de minimis rate rather than the developed country 1 percent de minimis rate, was not definitively resolved by Commerce in the proceeding. The preliminary CVD determination treated only one CVD rate below 1 percent as de minimis $^{174}$ (with a 1.69 percent rate not so treated). This was done without comment by Commerce. In the final determination, the only CVD margin below 2 percent was also below 1 percent. ${ }^{175}$ Consequently, Commerce formally treated the issue of rates between 1 percent and 2 percent as moot, ${ }^{176}$ leaving that determination to the next CVD action but with a strong implication that the more beneficial 2 percent rate will not likely be applied to Vietnam. ${ }^{177}$

\section{B. The Determination of Dumping}

Unfortunately, the preliminary $\mathrm{AD}$ determination in PRCBs provided no discussion of such key issues as choice of surrogate

170 Id. at 45817; PCRB Final CVD Decision Memo, supra note 10, at 7.

171 PCRB Final CVD Decision Memo, supra note 141, at 6-7.

172 Id. at 9-10.

173 PRCB Preliminary CVD Determination, 74 Fed. Reg. at 45819.

174 See PRCB Preliminary CVD Determination.

175 See PCRB Final CVD Decision Memo supra note 10 at 16340.

176 PCRB Final CVD Decision Memo, supra note 10, at 15; see PRCB Preliminary CVD Determination, supra note 9, at 45820.

177 PCRB Final CVD Decision Memo, supra note 78, at 15; see PRCB Preliminary CVD Determination, supra note 9 , at 45820. 
country for factors of production because of the decision to use adverse facts available (AFA). Nor was there any further analysis of such issues in the final determination; the punitive AFA was the basis of the final margins there as well. ${ }^{178}$ As Commerce noted in the final determination, "Because no party submitted case briefs and there are no other circumstances which warrant the revision of the Preliminary Determination, the Department has not made changes to its analysis, or the dumping margins calculated, with respect to the Preliminary Determination."

However, Commerce confirmed in the preliminary determination its willingness to use "separate rates" for calculating export price for many Vietnamese respondents. ${ }^{180}$ Otherwise Commerce provided little new guidance as to how it will be administering $\mathrm{AD}$ actions against Vietnam. As is normal practice when there are numerous foreign producers, Commerce selects a small number of major producers as mandatory respondents, in this case API and Fotai Vietnam. ${ }^{181}$ Given that both withdrew abruptly from the proceeding in September and October 2009, ${ }^{182}$ Commerce used the margin data provided by the petitioners as the AFA rate. Thus, dumping margins of 76.11 percent, the highest rate alleged in the petition was assigned to these two firms and for a number of others that did not complete "quantity and value" questionnaires sent to them. ${ }^{183}$

For the group of respondent enterprises that both completed $\mathrm{Q} \& \mathrm{~V}$ questionnaires and made proper requests for separate rate status, the margins were set at 52.3 percent. ${ }^{184}$ In reviewing separate rate requests, Commerce divided the requesters into three groups: producers that were totally foreign owned; joint ventures of foreign and local enterprises or those locally owned by private

178 Telephone Interview with Zev Primor, Senior International Trade Analyst, International Trade Administration (Nov. 9, 2009).

179 PRCB Final AD Determination, 75 Fed. Reg. 16434 (Apr. 1, 2010).

180 See PRCB Preliminary CVD Determination, 74 Fed. Reg. at 45820.

181 PCRB Preliminary AD Determination, 74 Fed. Reg. 56813, 56814 (Nov. 3, 2009).

182 Id. at 56815.

183 Id. at 56818.

184 Id. at 56817. 
groups; and those wholly owned or partially owned by the state. ${ }^{185}$ With the group of wholly-foreign owned producers, and in the absence of any evidence to the contrary, Commerce effectively presumed that the firms determined prices freely of Vietnamese government control. For the separate rate applicants that were joint ventures with Vietnamese owned companies or whollyVietnamese owned companies, Commerce analyzed the relevant de jure and de facto criteria for separate rates. ${ }^{86}$ In finding an absence of de jure government control, Commerce determined that all had demonstrated a lack of restrictive stipulations in the individual exporters' business and export licenses and legislation as well as formal measures decentralizing control of the Vietnamese companies. ${ }^{187}$

Commerce also determined that the applicants had demonstrated the absence of de facto control, through showing that each set export prices without government approval, possessed the authority to negotiate and sign contracts and other agreements, made autonomous decisions in selecting management and in disposition of profits or financing of losses. ${ }^{188}$ For the applicants that were wholly or partially state-owned, Commerce determined a similar absence of government control justifying the use of separate rates. Only those companies not seeking separate rates were assigned the Vietnam-wide government rates.

Unfortunately for the enterprises that qualified for separate rates for determining export price, Commerce was determined to use AFA, and choose the margin rates specified in the petition. However, Commerce effectively rewarded those who had applied for separate rates by setting their margin rates at a simple average of the rates alleged in the petition ( 52.3 percent) instead of the highest petition rate (76.11 percent) assigned as the Vietnamesewide rate and the rate given to the non-cooperating enterprises. ${ }^{189}$ The proceeding demonstrates that despite the lack of treatment of industry sectors as market economy industries, Commerce remains open to approving separate rate treatment of export price in

185 Id. at $56815-18$.

186 PCRB Preliminary AD Determination, 74 Fed. Reg. at 56816.

187 Id.

188 Id.

189 Id. at 56817. 
appropriate circumstances.

\section{The USITC's Material Injury Analysis}

As might have been expected, the USITC found in its preliminary determination that imports of PRCBs from Vietnam (along with those from Indonesia and Taiwan) evidenced a "reasonable indication" of material injury to U.S. producers. ${ }^{190}$ More than ninety percent of the USITC's preliminary injury findings are positive, not a surprising result given the low threshold for a preliminary injury finding. However, several factors in the preliminary finding suggested that a final injury finding was not certain. The cumulation of imports from the three foreign sources is standard practice. In this instance, the volume of imports did not increase consistently over the three years of the investigation, declining from 2007-2008, although the import market share did rise. ${ }^{199}$ Capacity utilization for the U.S. domestic industry declined slightly, but remained relatively high, at 82.4 percent in $2008 .{ }^{192}$ Although it found causation of injury as a result of imports, the USITC also noted that there was a seven percent decline in overall U.S. consumption during the period, which "may have had a role in the domestic industry's deteriorating performance during the period of investigation."193 There also remained questions as to the impact on the domestic industry of "nonsubject imports," imports not subject to antidumping or CVD investigations.

Nevertheless, in the final determination the USITC found by a vote of 5-1 that imports of PRCBs constituted a threat of injury to domestic producers. ${ }^{194}$ In reaching this conclusion the USITC cumulated imports from Vietnam, Taiwan and Indonesia, although Taiwan and Indonesia had been subject only to antidumping investigations. The Commission's analysis was complicated by

190 U.S. Int'l Trade Comm'n, Polyethylene Retail Carrier Bags from Indonesia, Taiwan, and Vietnam, Inv. Nos. 701-TA-462 and 731-TA-1156-1158, at 25 (Preliminary) (May 2009).

191 Id. at 20.

192 Id. at 23.

193 Id. at 25.

194 U.S. Int'l Trade Comm'n, Polyethylene Retail Carrier Bags from Indonesia, Taiwan, and Vietnam, Inv. Nos. 701-TA-462 and 731-TA-1156-1158 (Final) (Apr. 2010), at 38 [hereinafter USITC Final PRCB Determination]. 
the fact that the industry's flattening or declining due to a variety of factors, including environmental laws and increased use of reusable bags, as well as a weak economy, increasing costs and consumer perceptions. ${ }^{195}$ Moreover, some of the U.S. PRCB producers were themselves importing bags; the Commission refused to discount those volumes. ${ }^{196}$ Evidence of price underselling was mixed; in some categories imported PRCBs were higher in price than domestic products, and the Commission found no evidence of price depression during the period, ${ }^{197}$ but concluded that price depression was likely in the future because of the substitutability of imported product. ${ }^{198}$ Because of the many factors other than imports affecting the health of the domestic industry, the Commission could not "conclude that subject imports contributed more than marginally or tangentially to any material injury suffered by the domestic industry over the period."

As is often the case in threat determinations, the Commission also concluded that the principal foreign producers had both the ability and incentive to increase exports to the United States, as they were heavily dependent on the U.S. market. ${ }^{200}$ Relying on evidence of excess capacity and the "vulnerability" of the domestic industry, the Commission concluded that foreign producers were likely to fill excess capacity by increasing exports to the United States, and would have to undersell domestic producers in order to do so. ${ }^{201}$ Also, according to the Commission, predicted flat or declining U.S. demand would not "break the causal link" between imports and the "imminent" threat of material injury. ${ }^{202}$

One commissioner dissented, concluding that imports from producers not subject to the investigations were taking market share not from domestic producers, but from producers in China, Malaysia and Thailand that had been subject to antidumping

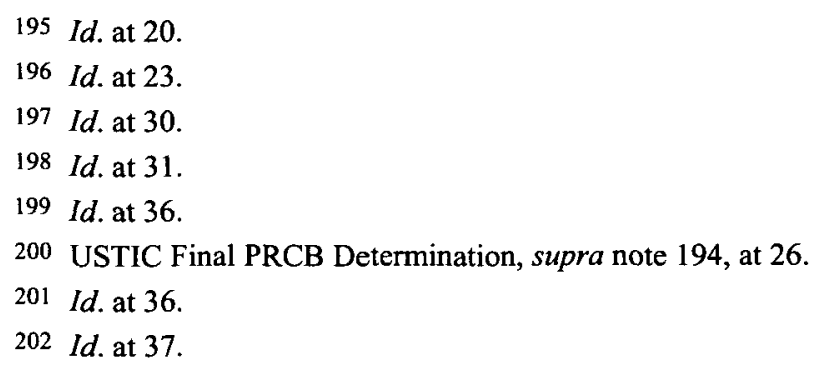


orders since 2004, and who had redirected production to Taiwan, Indonesia and Vietnam. ${ }^{203}$ The dissent also noted, inter alia, the correlation between domestic production and changing U.S. demand, reduced capacity utilization as a result of increased domestic production capacity, and the improvement in the domestic industry's operating margins in 2009. ${ }^{204}$ For the dissent, there was "no likelihood of any imminent significant negative impacts on the domestic industry from subject imports."205

Given that the USITC finds material injury or threat of material injury in a substantial majority of the cases before it, it was unlikely from the outset that Vietnam would avoid antidumping and countervailing duties as a result of a negative injury finding, despite the weaknesses in the domestic PRCB producers' case for injury. Accordingly, antidumping and countervailing duty orders, ordering the collection of cash deposits on imports after May 4, 2010 in the amounts of 52.30 percent (76.11 percent for firms treated in the aggregate as Vietnam-wide entity) for antidumping duties and from 5.28 percent to 52.45 percent for countervailing duties (with one Vietnamese respondent, Chin Sheng Company, Ltd., exempted from the order because of a de mimimis 0.44 percent margin). ${ }^{206}$ There is no indication that Commerce made any effort to avoid double counting of elements in AD and CVD margins, making a WTO challenge likely.

\section{U.S. Methodology and Non-National Benchmarks in Market Economy Situations: Canadian Softwood Lumber ${ }^{207}$}

One of the most significant (of many) DSB challenges of U.S. CVD laws is the softwood lumber dispute with Canada. It

203 See id. at 41-42 (dissenting views of Vice Chairman Daniel R. Pearson).

204 See id. at 50.

205 Id.

206 Antidumping Duty Orders: Polyethylene Retail Carrier Bags from Indonesia, Taiwan, and the Socialist Republic of Vietnam, 75 Fed. Reg. 23667, 23669 (May 4, 2010); Polyethylene Retail Carrier Bags from the Socialist Republic of Vietnam: Countervailing Duty Order, 75 Fed. Reg. 23670, 23671 (May 4, 2010).

207 This section is adapted in part from GREGORY W. BOWMAN, NICK COVELLI, David A. Gantz \& Ihn Ho Uhm, Trade Remedies IN North America, Ch. 12 (Ross Buckley \& Andreas Ziegler, eds., Kluwer Law Int'l, 2010). 
represents the longest-running (since 1982) and perhaps most bitter trade dispute ever between the United States and Canada. ${ }^{208}$ Unlike some others, the lumber dispute also affects a substantial volume of trade. ${ }^{209}$ For many years Canada has been the major source of lumber imported into the United States, 18 billion board feet (BBF) in 2000 worth $\$ 7$ billion, accounting for roughly thirtythree percent of the U.S. lumber market. ${ }^{210}$ Antidumping and countervailing duty deposits worth approximately $\$ 5$ billion were collected on U.S. lumber imports from 2002 to 2006 . Lumber production has been a major part of the economies of British Columbia (from whence about 60 percent of Canadian exports originate) Ontario, Washington and Oregon, among other Canadian and U.S. states and provinces. ${ }^{211}$ Some seventy percent of Canada's softwood lumber is exported to the United States, and the United States is the only major market for Canadian lumber. ${ }^{212}$

Softwood Lumber is relevant to the other issues discussed in this article because, with regard to the most significant element in the CVD action, the United States used a non-national benchmark, effectively treating the Canadian lumber sector as subject to NME rules because the Canadian provinces effectively control the market and set prices for standing timber sold to the industry, to the virtual exclusion of commercial sources of standing timber. Such treatment, as discussed below, is authorized under Article 14 of the SCM agreement. ${ }^{213}$ The proceeding also demonstrates that the key "benchmark" issue is analogous to those raised in CVD actions against China and Vietnam.

Accordingly, this section discusses only the CVD aspects of the "Lumber IV" phase of the proceedings before the Commerce Department that began in 2001, and only the non-national

208 Runsheng Yin and Jungho Baek, The US-Canada Softwood Lumber Trade Dispute: What We Know and What We Need to Know, 6 FOREST POL'Y AND ECONOMICS $129,129-31$ (2004).

209 See id. at 129.

210 Id. at 129-143.

211 Id. at 132.

212 M. Hart and B. Diamond, The Cul-de-Sac of Softwood Lumber, Public OPINION, Nov. 2005, at 19.

213 See Agreement on Subsidies and Countervailing Measures, art. 14, available at http://www.wto.org/english/docs_e/legal_e/24-scm.pdf. 
benchmark issue. ${ }^{214}$ Lumber IV was initiated following the expiration of a settlement agreement. ${ }^{215}$ The U.S. lumber industry, supported by various environmental and aboriginal interests, wasted no time after the expiration of the 1996 SLA; petitions were filed on April 2, 2001. ${ }^{216}$

\section{A. Commerce's CVD Investigation}

The most significant aspect of Commerce's final CVD determination, ${ }^{217}$ more so than the initial subsidy margins of 18.79 percent, ${ }^{218}$ was the position of Commerce on the issue of whether a cross-border price comparison could be used to determine the "benchmark" commercial price for harvested timber to be compared against the allegedly subsidized Canadian provincial government stumpage. ${ }^{219}$ The essence of Commerce's position was as follows:

In light of the objective [of the laws and regulations], we agree that a market benchmark prices chosen from the exporting country is preferable to a price chosen from outside the country because it is more likely that such a benchmark will more closely reflect, or be more easily adjusted for, prevailing market conditions in the country of provision in terms of overall price, quality, availability, marketability, transportation and other conditions of sale.

214 The proceeding also resulted in several WTO rulings on the AD case and on the threat of material injury determination by the U.S. International Trade Commission, as well as a series of NAFTA, Chapter 19 and U.S. federal court determinations.

215 Softwood Lumber Agreement, U.S.-Can., May 29, 1996, 35 I.L.M. 1195.

216 See U.S. Lumber Producers to File CVD, AD Case April 2 When U.S.-Canada Agreement Expires, 18 INT'L TRADE REP. (BNA) 437 (Mar. 15, 2001).

217 Notice of Final Affirmative Countervailing Duty Determination and Final Negative Critical Circumstances Determination: Certain Softwood Lumber Products from Canada, 67 Fed. Reg. 15545 (Apr. 2, 2002). The detailed analysis is contained in the accompanying unpublished decision memorandum (67 ITADOC 15545).

218 Gilbert Gagné, The Canada-US Softwood Lumber Dispute: A Test Case for the Development of International Trade Rules, 58(3) INT'L J. 335, 358 (2003), available at: http://www.jstor.org/stable/40203863 (Can.).

219 Issues and Decision Memorandum: Final Results of the Countervailing Duty Investigation of Certain Softwood Lumber Products from Canada from Bemard $T$. Carreau, Deputy Assistant Secretary for AD/CVD Enforcement II to Faryar Shirzad, Assistant Secretary for Import Administration (March 21, 2001), available at http://ia.ita.doc.gov/frn/summary/canada/02-7849-1.txt; supra note 147. 
However, if there is no market benchmark price available in the country of provision, it is obviously impossible to determine adequacy of remuneration except by reference to sources outside the country. ${ }^{220}$

Commerce concluded that there were no market-based internal Canadian benchmarks because of the dominance of government timber sales in the various provincial markets; under such circumstances, "true market prices may not exist in the country or it may be difficult to find a market price that is independent of the distortions caused by the government's action." ${ }^{221}$ American stumpage (selling price for standing timber), in contrast, is a reasonable benchmark. ${ }^{222}$ It is available to Canadian as well as U.S. producers and some Canadian producers have purchased U.S. stumpage. ${ }^{223}$ Also, the timber stands are comparable.

Softwood Lumber demonstrated that Commerce is prepared to exercise considerable discretion in making CVD determinations, regardless of the exporting country, even if that means that a market economy, such as Canada, is treated otherwise in particular circumstances and with regard to specific determinations of benefits.

\section{B. The WTO Appellate Body Decision}

Of the multiple challenges to United States administrative decisions, Canada's WTO challenge to Commerce's final CVD determination produced the most significant victory for the United States in terms of confirming, at least in principle, the right of the United States to use a non-national benchmark. ${ }^{224}$ For Canada, there was little to welcome. First, the Appellate Body (like the Panel) rejected Canada's challenge to Commerce's conclusion that when a province provides standing timber to a timber harvester in a stumpage program, it is a "good" that, when provided by the

220 Id.

221 Id.

222 See id.

223 See id.

224 See Appellate Body Report, United States - Final Countervailing Duty Determination With Respect to Certain Softwood Lumber from Canada, WT/DS257/AB/R (Jan. 19, 2004), available at

http://www.wto.org/english/tratop_e/dispu_e/cases_e/ds257_e.htm. 
government, constitutes a "financial contribution" within the definition of a subsidy in the SCM Agreement. ${ }^{225}$ More significantly (and highly relevant for U.S. CVD actions against China and Vietnam), the Appellate Body explicitly confirmed that despite the directive in SCM Agreement Article 14(d), "[t]he adequacy of remuneration shall be determined in relation to prevailing market conditions for the good or service in question in the country of provision or purchase., ${ }^{, 26}$ The United States could "use a benchmark other than private prices in the country of provision, when it has been established that private prices of the goods in question in that country are distorted, because of the predominant role of the government as a provider of the same or similar goods.",227

However, the Appellate Body did not "complete the legal analysis" (due to lack of sufficient facts in the record before the panel and transmitted to the Appellate Body) and determine whether or not Commerce's use of U.S. stumpage was an appropriate benchmark under the circumstances of the present case. $^{228}$ One can speculate that in the pending WTO action by China against the United States, the United States will point to Softwood Lumber as evidence that the United States is not discriminating against China in its CVD methodology (at least regarding this issue).

In the only other issue of major importance, the Appellate Body upheld Canada's demand that when considering whether alleged subsidies affect certain log and lumber producers it must do a pass-through analysis. ${ }^{229}$ Where a timber harvester sells some logs to unrelated sawmills, the Appellate Body concluded that Commerce had improperly failed to conduct a pass-through analysis to determine whether the subsidy to the timber harvesters was passed through to the unrelated purchasers of the logs. ${ }^{230}$ However, where the timber harvester processes the logs it

225 Id. If 76; Agreement on Subsidies and Countervailing Measures, art. 1.1(a)(1)(iii), available at http://www.wto.org/english/docs_e/legal_e/24-scm.pdf.

226 Id. ๆ 85.

227 WT/DS257/AB/R, supra note 224, ๆ 103.

228 Id. at 9122.

229 See id. 1146.

230 See id. ๆ $155-157$ 
purchases into softwood lumber, and sells that lumber to other mills for further processing, no pass-through analysis is necessary. ${ }^{231}$ In the latter situation, the products of both the timber harvesters and remanufacturers were subject to the investigation, and there is thus no need to analyze pass-through between producers of products subject to the investigation. ${ }^{232}$ This reflects treatment of the "upstream subsidies" issue that has been a factor in several Chinese cases, but not in PCRBs.

The United States purported to comply with the WTO determination when it issued its compliance determination, ${ }^{233}$ but Canada objected to Commerce's failure to carry out the passthrough analysis properly and its failure to apply that analysis to the first administrative review of the CVD order. ${ }^{234}$ The Appellate Body upheld the panel determination that the first review was required to incorporate the pass through analysis and thus was within the scope of the 2005 (Article 21.5) proceedings. ${ }^{235}$ Because of the 2006 settlement agreement, the United States and Canada consented to discontinue all pending WTO actions concerning softwood lumber. ${ }^{236}$

\section{WTO Challenges to U.S. Methodology}

While China is not effectively able to attack U.S. NME methodology in $\mathrm{AD}$ and CVD cases in principle, it has recently filed a broad challenge to such methodology "as applied" in four $\mathrm{AD} / \mathrm{CVD}$ actions. ${ }^{237}$ The issues raised include the treatment of

231 See id. ๆ 158.

232 See id. ๆ $159-165$.

233 See 232 Uruguay round Agreements Act § 129, 19 U.S.C. § 3538 (1994).

234 See Appellate Body Report, United States - Final Countervailing Duty Determination With Respect to Certain Softwood Lumber from Canada, Recourse by Canada to Article 21.5 of the DSU, WT/DS257/AB/RW (Dec. 5, 2005), available at http://www.wto.org/english/tratop_e/dispu_e/cases_e/ds257_e.htm.

235 See id. I 90-92. DSU, art. 21.5 provides the opportunity for further panel/Appellate Body review when Members disagree on whether the measures taken to comply with a WTO agreement by the responding party are consistent with the recommendations and rulings of the original panel/Appellate Body reports.

236 See Notification of Mutually Agreed Solution, United States - Final Countervailing Duty Determination with Respect to Certain Softwood Lumber from Canada, WT/DS257/26 (Oct. 12, 2006), available at http://www.wto.org/english/tratop_e/dispu_e/cases_e/ds257_e.htm.

237 Request for the Establishment of a Panel by China, United States - Definitive 
SOEs as public bodies that provided goods at less than adequate remuneration; provision of land rights at concessional rates; treatment of commercial banks as "public bodies" that are "entrusted and directed" to provide loans [at preferential rates] to specific industries; the use of benchmark rates outside of China for determining benefits; and failure to provide proper consultation with the Chinese government. ${ }^{238}$ A similar challenge was lodged in July 2009 against the EU Commission's actions. ${ }^{239}$ Many of these same objections are likely to be present when CVD actions are eventually challenged in the DSB by Vietnam.

One of the areas in which the United States may ultimately be vulnerable, relates to paragraph 15(a)(i) of the Accession Agreement, which appears to contemplate an analysis by the investigating authority as to whether market conditions may prevail in the specific industry under investigation. ${ }^{240}$ It is telling that Commerce has not found this to be the case in any of the dozens of antidumping actions brought against Chinese producers, although the burden of proof is not with Commerce but with the Chinese producers to demonstrate ME status in their industry sector. Commerce continues to take the position, despite its change in policy with regard to CVD actions that China (like Vietnam) remains an NME. ${ }^{241}$ Thus, in a recent case, Commerce stated that "the limits the GOC [Government of China] has placed on the role of market forces are not consistent with recognition of China as a market economy under the U.S. AD law."242

Independent of this issue is the question of double counting of $A D$ and CVD margins, given the difficulty of determining in an

Anti-Dumping and Countervailing Duties on Certain Products from China, WT/DS379 (Dec. 12, 2008), available at http://www.wto.org/english/tratop_e/dispu_e/cases_e/ds379_e.htm.

238 Id.

239 See Request for Consultations by China, European Communities - Definitive Anti-Dumping Measures on Certain Iron or Steel Fasteners from China, WT/DS397/1 (Aug. 4, 2009), available at http://www.wto.org/english/tratop_e/dispu_e/cases_e/ds397_e.htm.

240 Accession Agreement, Accession of the People's Republic of China, WT/L/432 (Nov. 23, 2001) available at http://www.wto.org/english/thewto_e/acc_e/completeacc_e.htm\#vnm.

241 See Coated Free Sheet Paper Decision Memorandum, supra note 121, at 36.

242 Id. at 37. 
NME situation the extent to which a domestic subsidy may also be reflected in dumping margin analysis. ${ }^{243}$ As with China, it remains extremely difficult, because of the WTO Accession Agreement for Vietnam, to challenge "as such" the application of CVDs to Vietnam and its producers. Rather, Vietnam will likely choose to focus on "as applied" issues when and if the appropriate Commerce action is presented. ${ }^{244}$ This limited opportunity for challenge is reflected in Vietnam's first request for consultations relating to U.S. AD (but not CVD) practice. ${ }^{245}$ In US - Shrimp (Vietnam), Vietnam has restricted itself to challenging the U.S. practice of "zeroing," already the subject of nearly a dozen successful WTO challenges by market economies, ${ }^{246}$ and to raising a number of technical issues. ${ }^{247}$

\section{Conclusion}

The CVD action against Vietnamese PRCB producers furnishes considerable insight as to the precise methodology Commerce will likely use in future CVD investigations against Vietnamese producers. Not surprisingly that methodology closely tracks the methodology used for China, both with regard to the initial decision to apply the U.S. CVD laws to Vietnam, and in determining which alleged subsidies are actionable and what benchmarks to use in calculating the benefit, if any, conferred, particularly with regard to interest rates. As with China, Commerce will likely use a mix of Vietnamese and surrogate data for the determination, perhaps with greater reliance on surrogate

243 For a detailed discussion of the double-counting issue, see Thi Anh Nguyet Le and Hong Quy Mai, Double Counting in the US Legislation against Non-Market Economies: 'As Such' and 'As Applied' Analysis, 7 MANCHESTER J. INT'L ECON. L. 71, 75 (2010).

244 PRCBs will likely not be such a case as the Vietnamese respondents appear to have abandoned efforts to defend their interests against U.S. authorities.

245 See Request for Consultations, United States - Anti-Dumping Measures on Certain Shrimp from Viet Nam, WT/DS404/1 (Feb. 1, 2010), available at: http://www.wto.org/english/tratop_e/dispu_e/cases_e/ds404_e.htm.

246 Raj Bhala \& David Gantz, WTO Case Review 2009, 27 ARIZ. J. INT'L \&COMP. L. 85, 152-77 (2010).

247 See Request for Consultations by Viet Nam, United States - Anti-Dumping Measures on Certain Shrimp from Viet Nam, WT/DS404/1 (Feb. 4, 2010), available at http://www.wto.org/english/tratop_e/dispu_e/cases_e/ds404_e.htm. 
data for dealing with possible subsidies in real estate. Softwood Lumber nevertheless remains the first major use by Commerce of non-national (surrogate) data for determining benchmarks in U.S. CVD actions.

The dumping determination in PRCBs provides no useful indication of the extent to which Commerce is willing to recognize Vietnam's movement toward market economy status, since the existing NME status was not challenged by respondents in the proceeding. Ironically, only the discussion of the use of CVD actions against Vietnam reflects recognition by Commerce, albeit indirectly, of the progress Vietnam is making toward market economy status. That determination also leaves open the logical economic disconnect between $\mathrm{AD}$ actions using NME surrogate country methodology and CVD actions based in part on the use of national data to calculate the benefits derived from government subsidies. Notwithstanding this dichotomy one can be reasonably sure that parallel $\mathrm{AD} / \mathrm{CVD}$ actions will be the rule rather than the exception with U.S. unfair trade actions against both China and Vietnam until the Accession Agreement authorization for such treatment expires in 2015 and 2018, respectively, despite the possible success of "as applied" WTO challenges to subsidiary issues such as double-counting. 
